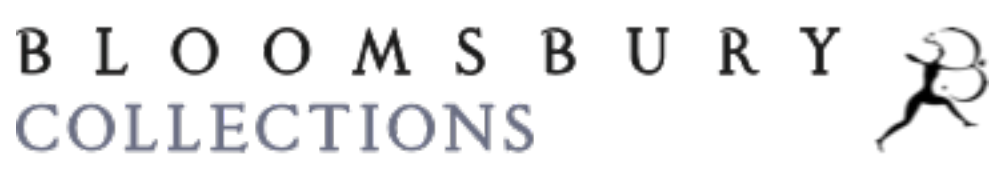

Manning, Roger B. "The Search for a Science of Peace." War and Peace in the Western Political Imagination: From Classical Antiquity to the Age of Reason. London: Bloomsbury Academic, 2016. 215-270. Bloomsbury Collections. Web. 26 Apr. 2023. <http:// dx.doi.org/10.5040/9781474258739.ch-005>.

Downloaded from Bloomsbury Collections, www.bloomsburycollections.com, 26 April 2023, 07:49 UTC.

Copyright ( Roger B. Manning 2016. Released under a CC BY-NC-ND licence (https:// creativecommons.org/licenses/by-nc-nd/3.0/). You may share this work for non-commercial purposes only, provided you give attribution to the copyright holder and the publisher, and provide a link to the Creative Commons licence. 


\section{The Search for a Science of Peace}

Warfare has no place among the useful arts. Nay, rather it is so horrible that only the utmost necessity, or true affection, can render it honourable.

Hugo Grotius, The Law of War and Peace: De Jure Belli ac Pacis Libri Tres, trans. Francis W. Kelsey, 2 vols. (Washington:

Carnegie Institution, 1913-25), II: xxv. ix. 3 (pp. 585-86)

That is the best government which best provides for war.

Algernon Sidney, Discourses concerning Government (London: various booksellers of London and Westminster, 1698), bk. II: 23

The conflict between martial culture and the peace ethic was one of the main themes of humanist thought; in the seventeenth century, these topics were elevated to a more theoretical level of discourse in the writings of Alberico Gentili, Hugo Grotius, Thomas Hobbes, and the classical republican followers of Niccolò Machiavelli. Warfare and military preparedness were at the center of Machiavelli's political discourse, and everything else was of secondary importance. In the age of religious wars, Gentili had to flee his native Italy because he had become a Protestant; he subsequently found refuge in Elizabethan England. Grotius, who witnessed much of the Eighty Years War in the Low Countries, also had to deal with the problem of war overwhelming politics. ${ }^{1}$ Hobbes lived through both the English civil wars in the 1640s and the Fronde in France in the 1650s. All four political philosophers shared the common experience of being forced into exile or flight by war, political factionalism, or religious persecution. Gentili believed that there were no natural causes that justified going to war because all men have a kinship to one another: "If there seems to be a natural enmity between two peoples, then it is 
because they are trained to be enemies of one another. But this is the result of education, which is a second nature." ${ }^{2}$ Grotius went on to provide a language of natural law that furnished a theory of natural rights and a foundation for international law, which in more recent times, has helped to provide a number of constraints on how wars have been fought as well as a series of rules governing the behavior of sovereign states. Their experience of interstate and civil war gave both Grotius and Hobbes an abiding dislike of violent conflict. Hobbes, who learned to distrust the inflammatory rhetoric of ambitious politicians in democratic governments from his study of Thucydides, preferred to trust the security of the commonwealth to an absolute sovereign. For this reason, he has never been appreciated for his endeavors to promote the scientific study of peace until quite recently. The classical republicans, the principal heirs of Machiavelli in the Atlantic world, continued to insist that citizens of states with popular governments who valued their liberty must be prepared to give their blood to maintain those political traditions.

\section{Gentili and Grotius: Natural law and constraints on war}

As we have seen, Justus Lipsius, along with Gentili and Grotius, was one of the founders of international law because he had sought to synthesize Stoic ethics and Christian morality and apply these principles on a case-by-case basis to the same topics that Machiavelli wrote about, thus introducing a moral dimension to political theory that was missing in Machiavelli. Lipsius further applied Dutch social and moral values not only to the task of waging war, but also to an attempt to prevent the blight of war from disrupting the lives of civilians while at the same time protecting trade and the economy. Lipsius's values were distinct from aristocratic preoccupations with honor, glory, and privileged status. Like Hobbes, he leaned in the direction of absolutism, preferring peace and stability to individual freedom. ${ }^{3}$

The political philosophers of the seventeenth century recognized that rational and scientific explanations of the causes of war were not to be found in divine commands, Divine Providence or man's sinful nature. A more fruitful approach could be discerned in the study of what we term political and social structures and in the animosity generated by conflicting religious views. 
Algernon Sidney recognized that the function of the feudal nobility had been making war; they were "perpetually in arms" because they placed a high value on valor and were acquisitive. ${ }^{4}$ The Scots political theorist Andrew Fletcher observed that a profound alteration in government had occurred in most European countries in about 1500 whereby kings who possessed greater financial resources began to keep armies standing in peacetime as well as war. The nature of warfare quite altered as missile and gunpowder weapons replaced edged weapons, and the aristocracy gave up martial pursuits and were replaced by professional officer corps. "Thus, the armies which in preceding times had always been composed of such men as these, ceased ... and the sword fell out of the hands of the barons." Princes began instead to raise standing armies paid for by levying taxes voted by representative assemblies and levied on "people grown rich by trade, and dispirited for want of military exercise." War became more pervasive in the sixteenth and seventeenth centuries "and grew a constant trade to live by." The nobility adjusted to the changed conditions by taking up military commissions in the officer corps of these new professional armies. ${ }^{5}$

The Italian jurist Alberico Gentili viewed the laws of war as a subdivision of international law. He was forced to flee his homeland and seek refuge in England because he had converted to Protestantism. In England, he became a protégé of Robert Dudley, Earl of Leicester and Chancellor of Oxford University, who secured a position teaching Roman law for Gentili in 1580. In 1587, he was appointed Regius Professor of Law on the recommendation of Sir Francis Walsingham. Gentili later attracted the attention of Robert Devereux, second Earl of Essex, who was a member of the Elizabethan war party. Gentili was an admirer of Machiavelli and shared some of the views of classical republicans, but he also became, as we now understand, one of the founders of the corpus of international law. The study of this discipline was based on natural law rather than divine law or theology. The debate that Gentili participated in did not concern whether war was a just instrument of the state, but rather focused on the variety of justifications for war. ${ }^{6}$

Gentili insisted that the laws of war arose from natural law because they concerned the whole human community, and did not derive from the teachings of political or moral philosophers. This was a premise to his argument that defensive war had to do with the duties of citizens and pertained to only one community, whereas a philosophy of war would be the concern of the whole 
human community and would comprehend enemies as well. Roman law, as embodied in the Justinian code, Gentili says, citing Jean Bodin, was ignorant of the laws of war. The concept of natural law was, however, known to the ancients, and they assumed that a common understanding of the laws of war could be derived from natural law, which was innate. However, the understanding of natural law varied from one man to another, according to his level of intelligence. ${ }^{7}$

Gentili maintained that war was a legitimate exercise of the power not only to defend one's country, but also to preserve the wider human community. He used this argument to justify the Spanish conquest of much of the New World, citing the unnatural practices of some of the American Indians, such as cannibalism, as violations of natural law. At the same time, Gentili rejected the Aristotelian argument that all barbarians were inferior, and could for that reason, be enslaved. However, because their moral standards diverged so widely from those of the Christian world, he distrusted the Turks, and took note of their barbaric behavior in the way that they waged war and enslaved conquered peoples. For this reason, Gentili believed that Christian monarchs should never enter into treaty relations with the Turks, as the king of France had done. ${ }^{8}$

Gentili excluded many varieties of human conflict and violence from the category of war. War must be public, just, and fought with the usual and customary weapons of war between two sovereign rulers, and it must be officially and publicly declared according to a mutually understood protocol, which included an announcement of intentions, an opportunity to make satisfaction for a stated grievance, and a waiting period. No war should be declared unless the need for such conflict was first demonstrated and arbitration attempted. Arbitration was the only available peaceful means for settling disputes. Moreover, there were many examples in former times of arbitration between sovereigns. Gentili also maintained that war should be waged only against armed combatants; he did not approve of the deliberate devastation of the lands, properties, and houses of noncombatants, or the deliberate destruction of works of art. He urged moderation in war and the avoidance of needless cruelty except against brigands and pirates, who were not protected by the laws of war. Gentili believed that the purpose of every war was to secure peace. Peace was "the orderly settlement of war." Permanent 
peace was best procured by ensuring that the terms imposed on the vanquished were just and moderate. The victors were entitled to reparations covering the cost of the war as well as the payment of tribute, but if the peace settlement did not embody justice, then the peace would not be lasting. Gentili quoted Seneca as saying that an unjust war was no better than organized murder. But he reminded his readers that the Romans never recognized rebels, brigands, and pirates, or participants in slave revolts as enemies entitled to be dealt with according to the rules of war. All could be summarily condemned to death. To be a recognized enemy, one had to be part of a sovereign state. ${ }^{9}$

The pursuit of war to seek vengeance was just, Gentili states, because the failure to seek vengeance invited another injury or wrong. The right of a sovereign to seek vengeance rose out of natural law. This was a natural right that had been allowed to individuals before the formation of political societies, but was now exercised by rulers and magistrates on behalf of individual citizens. The human causes of war consisted of violations by a sovereign state of manmade laws. From this perspective, war was simply an instrument for dispensing justice by avenging an injury and punishing a crime. However, Gentili admitted that this view of war was dangerous, and a war for such reasons should not be declared without first attempting arbitration. Preemptive strikes had been a frequent cause of war from antiquity to Gentili's time, and Gentili believed that preemptive strikes could be justified by fear of an injury rather than a real injury. There was no good reason to needlessly expose one's self to danger. This was sometimes used as an argument for making war on the indigenous peoples of the New World. ${ }^{10}$ It was possible, thought Gentili, for both parties to a war to have justice on their sides. It did not follow that in a war one side had justice entirely on its side, while the other belligerent was in the wrong. Gentili gave the example of the Jewish conquest of the land of Canaan by divine command, while the Canaanites, being ignorant of the divine command, were fighting a war of self-defense: "if it is doubtful on which side justice is, and each side aims at justice, neither side can be called unjust." 11

Gentili was also a strong advocate of religious toleration, and he argued that it was against natural law to force another person to change his religion against his will. Religious freedom should be allowed unless harm was done to the state thereby. He disagreed with Justus Lipsius, who believed that only one religion should be practiced in a state. Contrary to what Lipsius said on the 
matter, Gentili claimed that toleration in practice was allowed in the Imperial Free Cities and in the Habsburg lands of the Holy Roman Empire, as well as in the papal states, and it was also the practice of the Turks toward Byzantine Christians and Jews. ${ }^{12}$

Gentili's approach to formulating the rules of warfare and their place in the body of international law bears some resemblance to the Neo-Stoical and Salamancan schools of thought. His firm belief in religious toleration separates him from the Neo-Stoics, who believed in adherence to a state religion as a social glue to hold civil societies together in an age of religious warfare. Whereas members of the Salamancan School, such as Francisco de Vitoria and the Portuguese Jesuit Juan Luis Molina ignored classical authors and employed Thomist criteria to condemn many of the characteristics of modern warfare, such as the conquest of the New World, Gentili used humanist scholarship to approach classical authors in order to devise his rules of war. He also thought that Vitoria, Balthazar Ayala, and other members of the Spanish School did not pay enough attention to concepts of peace, and gave too much attention to matters concerning war. Gentili's English patrons, such as the second Earl of Essex, to whom he dedicated his De Jure Belli, drew him into the fringes of the Elizabethan war party, and his admiration for Machiavelli suggests that he displayed some of the characteristics of a classical republican. But he does not fit neatly into any of these categories. ${ }^{13}$

Grotius also drew most of his examples of unjust wars from the ancient world, but in addition, he addressed the contemporaneous problem of religious conflict by denying that the pope's claim to universal jurisdiction was justified by scripture or patristic authority, while at the same time, attacking Protestant claims for going to war based on ancient prophecies or the explicit command of God. Even when just causes for declaring war presented themselves, Grotius's counsel was not to do so rashly. ${ }^{14}$ Grotius, in effect, had undermined the legal authority of the Bible and provided a secular explanation for the causes of wars, and thus, had rejected the traditional medieval explanations of when war was justified. Grotius's determination to separate religion from politics and legal discourse represented a significant new direction in political theory. His treatment of war was based on natural law, which was discoverable by reason, and his examples were mostly drawn from classical antiquity. Thus, the rules governing warfare should be knowable to all men and not just Christians. ${ }^{15}$ 
The political theories of both Grotius and Hobbes were based on the assumption that men had once existed in a state of nature, and for mutual selfprotection, had made a compact to enter into political society. Sir Robert Filmer, the defender of patriarchalism and royalism, rejected Grotius's concept of a state of nature that existed before men entered into political society. Because all men were descendants of Adam, who was the first patriarch, political society had always existed. Filmer believed that Grotius had a bad influence on political theory because he conflated natural law and the law of nations. ${ }^{16}$ Filmer insisted that popular governments must always tend toward war and violence because the opinions of the people will always be so varied, and they lacked the judgment to distinguish between truth and falsehood. Only a king or a dictator could remedy this situation. Thus, popular government must always give rise to more tumults than the most tyrannical of monarchies. Like Grotius, Filmer drew most of his examples from ancient history to support his assertions: "The murders by Tiberius, Caligula, Nero, Domitian, and Commodus put all together cannot match the civil tragedy which was acted in that one sedition between Marius and Sulla.... This was the height of Roman liberty-any man might be killed that would. A favour not fit to be granted under a royal government." ${ }^{\prime 17}$

Whereas Algernon Sidney believed that civil society would dissolve without constant vigilance and military preparedness to defend liberty against tyrants, John Locke maintained that war, however just, was detrimental to civil society because men, when entering political society, gave up the right to make war as individuals. Arbitrary monarchs, by their ambition and aggression, caused the dissolution of political society and brought perpetual disorder. Their subjects thereby gained the right to wield the sword, and rebellion and resistance against the prince thereby became justified. ${ }^{18}$ In interstate wars, Locke attempted to impose legitimate limits on the objectives of war: The aggressor could be punished and reparations demanded. This meant that the offending government could be subdued or brought to terms, but the enemy could not be annihilated. The problem in securing a peace settlement was that just as man as an individual living in the state of nature experienced disorder and a lack of security, so also commonwealths experienced the same kind of insecurity because of the absence of a universally recognized body of international law and some universal authority to enforce the same. Consequently, it fell to individual states to be 
"both judge and executioner of the law of nature." Since men tended to be "partial to themselves, passion and revenge is very apt to carry them too far...."'

Hugo Grotius was appalled by the lack of restraint in war throughout the Christian world and the "rush to arms" for the slightest of pretexts. He did not believe that Erasmus's solution of forbidding Christians to take up arms was practical. Rather, Grotius set out to discover "a common law among nations" based on natural law, which would impose restraints on war and which would be understood and accepted by all men, whether civilized, enlightened or barbarian. This would be based on a prodigious knowledge of "philosophers, historians, poets ... [and] orators." ${ }^{30}$ Grotius said that "it should not be supposed that while a war rages all laws are in abeyance."21 Citing numerous Roman precedents, he stated that wars should be conducted with the same scrupulousness as judicial processes. Even though the courts may not be able to operate in wartime, there were laws that govern conduct in war as well as relations among people in time of peace. Wars should be waged only against those who refuse to abide by judicial decisions, and only in accord with recognized laws of war. ${ }^{22}$

Grotius's greatest contribution was to provide a legal and historical foundation for constraints on war. But it must be remembered that others, such as Balthazar Ayala, also made significant contributions to rules limiting the horrors of war. In addition, Grotius was also indebted for many of his ideas to the Spanish school of political theory concerning the origins of international law with regard to natural law and the laws of war. ${ }^{23}$ In the seventeenth century, the laws of war also evolved out of the codification of military customs and conventions by professional military officers in the capitulations of besieged fortresses, protocols for the ransom of prisoners of war, articles of war, and codes of military justice that imposed discipline on soldiers with regard to the distribution of lawful booty and the treatment of noncombatants. Among the earliest written instruments were articles of war drawn up by field commanders in the Dutch and Swedish armies in the times of Maurice of Nassau and Gustavus Adolphus. Such instruments were widely copied in the various armies that fought in the British civil wars, but the basic principles would have found approbation among the officers of mainland European armies. Ultimately, such customs and conventions had derived from chivalric culture, aristocratic codes of honor and conduct, and the teachings of the 
medieval Catholic Church. In the early eighteenth century, these laws of war, inherited from the professional soldiers of the seventeenth century, were praised by many of the philosophes as evidence of progress and humanitarianism in the conduct of war among European nations. ${ }^{24}$

Regardless of Grotius's poor opinion of the military profession-he considered mercenary soldiers more abominable than executioners because they kill without cause - the degree of status assigned to professional officers was rarely challenged. Indeed, the Seigneur de Saint Evremond, a French veteran of the Thirty Years War who lived in exile in England during the reign of Charles II, believed that the noble profession of arms made "subjects equal in authority to the sovereign." The question concerning whether a good Christian could be a soldier resulted in divided opinion within the Catholic Church in France. The Jansenists tended to condemn military life and discouraged careers in the army, but Jesuit chaplains organized confraternities within the army to minister to soldiers who wished to be pious. ${ }^{25}$

Despite repeated declarations of his aversion to war, Grotius went on to attempt to define when war was justified. Those who hoped for perpetual peace often cited the prophecy of Isaiah, ii. 4, of a time when swords will be beaten into instruments of cultivation, but Grotius insisted that this refers to a time in the future when all men will have become Christians and put aside un-Christian habits. Until that time, the world will continue to experience an age of iron. St. Peter's admonition that "he who smiteth with the sword shall perish with the sword" is not applicable to public war lawfully declared, but only to private war. According to Grotius, Christ did not intend to prevent the Christian from fighting in a lawfully declared, just war when he stated that his kingdom was not of this world (John xviii. 36). A public war was a lawful and formal war waged between two sovereign states. The possession of sovereignty assumes the legal right to declare and wage war. A private war is waged by someone who lacks the authority to wage war, but it is justified to wage private war to avoid an injury where no public tribunals exist. ${ }^{26}$ Grotius says that war is more than contending by force; it is a condition that persists over time. Bellum, or public war, often subsumes duellum, or private war, which is more ancient than public war. "War ... is undertaken in order to secure peace," but peace can exist only where factionalism and feuding have been suppressed to such an extent that we may speak of a political community as having achieved "union." ${ }^{27}$ 
Grotius reconciled the concept of a just war, lawfully declared, with natural law by arguing that war is not opposed to nature, but is in perfect accord with it, since nature has given every animal strength sufficient for self-defense. Right reason allows the use of force to protect oneself and one's possessions provided the rights of others are not infringed. Reason also dictates that this right to employ force in defense of one's rights should be exercised as a community. Thus, the right to forcibly resist an attacker to avoid an injury is a natural right, but with the establishment of civil society, the individual must yield that right of self-defense to the state, which in exchange for the obligation to protect the individual and his property, seeks to acquire a monopoly on violence, or at least, to limit the resistance that an individual can offer. Otherwise, the state cannot function. However, if a ruler violates the laws or becomes an enemy of his people, then his subjects have the right of forcible resistance, and may even put the tyrannical ruler to death. ${ }^{28}$

Grotius says that the best of Greek and Roman thinkers insisted that the laws cannot exist without sanctions, and that sometimes nations and rulers need to go to war to secure justice to themselves, but they must also remember that they were part of the human race, and their principles of justice needed to extend beyond their own borders, even to those who were their enemies. It was unwise not to adhere to the rule that concepts of justice needed to be shared in the wider international community because every state will someday stand in need of a defensive alliance or trade agreement in order to survive. To depart from this concept of international law and justice is risky. ${ }^{29}$ Grotius was very careful to specify the unjust causes of war in order to validate his just-war theories. The main distinction here was between "justifiable and persuasive causes." Following Polybius, he calls the first category "pretexts" because they were the reasons for going to war that were publicly alleged. The "persuasive" causes were the actual reasons for which a state or a sovereign undertook a war. Those who rushed into war without either pretexts of persuasive causes were no better than savages. Those who alleged pretexts for going to war, but had no justifying causes, were regarded by classical Greek and Roman authors as brigands. ${ }^{30}$

Grotius is sometimes considered an advocate of peace, but in fact, he was something less than a pacifist. First of all, Grotius justified the Dutch rebellion against Spanish rule because he thought that the duke of Alva prosecuted the 
war against the Dutch rebels in a manner that violated the king of Spain's oath to uphold the law. Moreover, the Dutch republicanism that Grotius espoused was bellicose and expansionist. During the Eighty Years War, he distanced himself from the party of Oldenbarnevelt, which advocated peace with Spain that subsequently resulted in the Twelve Years Truce of 1609 . He opposed this truce because members of his family had an interest in the United East India Company (VOC) and he believed that commercial expansion at the expense of Spain and Portugal was necessary to sustain Dutch republicanism. This was also a motive behind his advocacy of freedom of the seas in his Mare Liberum, which advocated the right of trading companies such as the VOC to wage war as if they were sovereign entities. ${ }^{31}$ In England, John Selden, who had at first opposed peace with Spain, changed his opinion on this matter and joined the court faction in supporting a rapprochement with Spain because he came to fear the growing power of the Dutch in both naval and commercial power. This was the occasion of Selden writing his Mare Clausum (1636) in answer to Grotius's Mare Liberum. ${ }^{32}$

\section{Classical republicans and martialism}

The classical republicans, especially the seventeenth-century English followers of Machiavelli, were at odds with the Grotian school of thought in their emphasis on a martial ethos. Like their Florentine mentor, the classical republicans saw liberty not as an end in itself, but as a means to a military end by seeking to imitate the military expansion of Rome rather than the stability of Venice. The reception of Machiavellian classical republicanism in England during the period of the English Commonwealth was accompanied by the conquest of Ireland and Scotland, and the defeat of the formidable Dutch navy during the First Anglo-Dutch War. Seventeenth-century England suffered from mostly weak or unstable governments, and consequently, was pervaded by a climate of war even during the periods when actual hostilities had subsided. For that reason, English political theorists such as Bacon, Harrington, Hobbes, Sidney, and Locke devoted much discussion to the subject. Those who inclined toward classical republicanism insisted that war was necessary to defend liberty, while those who sought to explain the endemic nature of 
warfare found abundance of sin and political failure a sufficient explanation. That historians and political scientists should associate the martial ethos with classical republicanism is hardly surprising since ancient Greece and the Roman Republic were perpetually at war, and this martial disposition made every citizen a soldier. The cultural antecedents of classical republicanism in the ancient world were self-destructive, and early modern political theorists, such as Machiavelli and Hobbes, sought to impose self-discipline, but war nonetheless remained a preoccupation of classical republican thought in the seventeenth century. ${ }^{33}$

One of the very first of the English classical republicans was Sir Francis Bacon, who like Machiavelli, insisted on the importance of a race of valiant men continually exercising arms in order to achieve civic greatness. Contrary to what some writers had maintained since antiquity, Bacon, like Machiavelli and Harrington, adhered to the somewhat old-fashioned view that it was valiant and well disciplined soldiers possessed of a warlike spirit that constituted the nervi belli, or "sinews of war," and not money. As important as riches and trade were to making war, Bacon insisted that one should never lose sight of the fact that poorer nations sometimes made war and achieved civic greatness more readily than those states that had grown wealthy, but had sunk into luxury and effeminacy. ${ }^{34}$ Even Thomas Hobbes had been more inclined to advocate war in his younger days. He began his career in the household of the Cavendishes, a military family, and he was closely associated with Sir Francis Bacon, who, in 1624, advocated a preemptive war against Spain and who was more "Hobbesian" than Hobbes himself in believing that "humanity is in a condition of public war of every man against every man."35 Hobbes was also involved in colonizing activities in Virginia and Bermuda during his association with Sir William Cavendish, later Lord Cavendish, who sat on the council of the Virginia Company. ${ }^{36}$

Algernon Sidney, perhaps the most bellicose of the classical republicans, believed that making war was one of the most important functions of a state, and that a state that did not change and expand must decline and disintegrate. This was based, in part, on the mercantilist assumption that the world contained a fixed amount of resources and competition was absolutely necessary for survival. The principal criterion for judging a government, whether a monarchy or a republic, was how well equipped they were with regard to the competence 
of their commanders and the fitness and loyalty of the people who furnished the state's soldiers. The commanders of the armies of popular governments must demonstrate competence and merit, whereas those of monarchies need only be favorites of the king. For this reason, a state should not depend on a single ruler to defend itself, but rather on citizens and magistrates who are trained in arms. Failure to provide for defense in this way should be regarded as a shameful thing. ${ }^{37}$

James Harrington, like Sidney, drew on Machiavelli's distinction between those republics that were expansionist and sought conquest, such as Rome and ancient Israel; those that were armed only for defense, such as Sparta; and those, such as Venice, that pursued peace and trade as a matter of policy. Sidney believed that all sought the public good. Rome was most successful in terms of its preparedness for war; Venice was the weakest because of its habit of depending on mercenary soldiers. As Jonathan Scott points out: "This unqualified bellicosity is the touchstone of Sidney's political thought." ${ }^{38}$ Having read what Machiavelli had to say about the various historical examples of republics, Sidney concluded that it was better for a state to be organized for both war and trade. It should be prepared to wage both offensive and defensive war, employing citizens as soldiers. Trade was useful in order to finance war, but it must be assigned a role inferior to making war. ${ }^{39}$

James Harrington was more interested in peace and stability than Sidney. Based on his study of classical Greek history, Harrington concluded that peace could only be secured by a government that sought a balance between the power of the aristocracy and the commonalty. In this commonwealth there must be liberty and property for the citizen as well as participation in government. Not to establish a government of this sort invited bloodshed. ${ }^{40}$ Harrington strongly disagreed with Machiavelli's assertion that what enabled Rome to expand its empire by military conquest was the arming of the plebeians, and that the cost of such greatness was the continuing problem of popular tumults that the Roman senatorial class had to tolerate. Harrington valued political stability more highly, and he thought that allowing the commonalty such a large share in government led to anarchy. Harrington agreed with Thucydides and Hobbes that the source of popular tumults and foreign wars was political passions and demagoguery, and in his Oceana, Harrington devised elaborate safeguards in his ideal commonwealth to defuse such passions by 
avoiding inflammatory oratory. Effectively, Harrington abolished freedom of speech and allowed such freedom only to written expression that would be regulated by "moderators." Harrington derived this "peace of silence" from Hobbes's translation of Thucydides' History of the Peloponnesian War (1629), which condemned political passions leading to unbridled rhetorical excess. During their reigns, James I and Charles I both complained of the inflammatory rhetoric in the English House of Commons. Hobbes had studied the politics of the classical world of Greece and Rome, and had found that they afforded an inappropriate model for seventeenth-century England. ${ }^{41}$

Harrington thought that maintaining a large standing militia that required military service was generally the best way to avoid war and secure peace. This standing militia that Harrington envisioned for England, Ireland, and Scotland would consist not of soldiers of fortune, but rather of "citizens at their vocations and trades." These citizen-soldiers would maintain a constant state of readiness, and would serve in the horse or foot according to their social rank. Although exempt from military service, persons above the age of thirty could volunteer for military service in order to gain honor. ${ }^{42}$

English writers in the late sixteenth and seventeenth centuries were much concerned about what they perceived to be a decline of the martial ethos. The reception of Tacitism caused them to view this as a problem of luxury causing sloth and a diminishment of manliness. Authors who had received a classical education further saw this as a decline from an earlier golden age. ${ }^{43}$ Sidney considered the noblemen and gentlemen who dominated the political life of Restoration England to be an "effeminate titular nobility" because they no longer exercised arms, and instead, based their claim to exalted position on "riches and birth." The implication was that they were less noble than the commoners who had recently taken up arms to defend the English Commonwealth during the Interregnum. For Sidney, the model aristocracy was the Anglo-Saxon nobility that had consisted of the whole of the citizenry because, in Anglo-Saxon England, all free men bore arms and were therefore noble. All others were villeins or slaves. Sidney had trouble accepting that feudalism was long since dead. $^{44}$

Sidney placed little value on peace. "Peace may be good in its season," but it had no absolute value; it was thought to be worth having only by those nations that did not value courage or justice. Human society was not constituted for 
peace: the world "being so far of another temper that no nation can be safe without valour and strength," which, as the leaders of the Roman Republic understood, could be achieved only by "discipline and exercise [of arms]." ${ }^{45}$ But, following the establishment of the Roman peace, citizens ceased to be employed as soldiers; their courage withered while plebeians were hired as soldiers for pay. They were eventually replaced by barbarians; consequently, Italy lacked men possessing the strength and virtue to defend the homeland. Sidney was both a relativist and a believer in progress. He thought that the early Church Fathers, such as Tertullian, St. Augustine, or St. Ambrose had nothing to say to his generation about the value of peace because the circumstances of political life changed constantly. The early Christians might turn the other cheek or seek martyrdom because they expected that death was imminent; as a persecuted minority, they were not focused on taking up the duties of citizenship or the office of magistrate. ${ }^{46}$ Arguing against Filmer, Sidney insisted that popular tumults, seditions, and wars could find moral justification. God did not intend that men should do wrong, nor did he say that they should suffer wrong, for that would be an injustice, which must be punished, whether in a malignant magistrate or in the violence offered by a foreign enemy. To fail to recognize that war and rebellion are justified in the face of cruel tyranny or gross injustice, where more peaceful methods of persuasion have failed, subverts the basic principles of law and virtue. ${ }^{47}$

The great poet of seventeenth-century England John Milton launched an attack on the remnants of the martial ethos and chivalric culture. His epic poem, Paradise Lost, begun in 1650 and published in 1667, was written for Englishmen who had long been subjected to "the odious din of war." ${ }^{38}$ His audience included not only those who had lived and fought through the three English civil wars, the conquest of Scotland and Ireland, and the First AngloDutch War, but also those whose memories reached back before the Wars of the Three Kingdoms began in 1638. Even before the beginning of these internecine and interstate conflicts, the English people had lived in a climate of war. Not only had Spain attempted to invade England several times after 1588, and actually landed in Ireland, thousands of soldiers from the British Isles had fought in the religious and dynastic wars of mainland Europe for the better part of a century prior to the British civil wars. There had developed in England and among English-speaking readers elsewhere an audience for a vast literature 
on every aspect of warfare-manuals on the art of war by classical and modern authors, war memoirs, sermons justifying war, and news books recounting the events in the mainland European wars. And of course, there were the secular works of political theory by Machiavelli and the classical republicans equating military preparedness and the exercise of arms with good citizenship as well as numerous works on medieval chivalry and the chivalric revival celebrating individual acts of valor and feats of arms. ${ }^{49}$

Milton's Paradise Lost relies heavily on military metaphors and martial discourse because military books were widely studied by members of the reading public among the country gentry and the citizens and burgesses of towns. There was a widespread belief in the inevitability of war that went beyond its acceptance as part of the human condition and that embraced the belief that honor needed to be validated on the field of battle. Milton was repelled by these values, but he makes use of this widely shared martial ethos to condemn war and to show how it was repugnant to reason, morality, and the teachings of religion. He uses poetic imagination to depict Satan and the fallen angels as possessing martial values and behaving like professional soldiers. Milton's Paradise Lost is meant to be a subtle attack on the notion that equates martial endeavors with true nobility and to persuade his reading audience to alter their views. Milton's condemnation of war is an attitude that was largely absent from previous ages, and was exceptional even in the Renaissance. ${ }^{50}$

The presence of Satan and his martial hosts in Paradise Lost reminds us that Milton is not offering us a secular explanation of the phenomenon of war. He realized that it was difficult, if not impossible, to provide rational alternatives to the crusading mentality of divines and preachers when so many great thinkers of antiquity and the modern world had failed to come up with an escape from the belief in the inevitability of war. Milton continued to offer a theological explanation for the pervasiveness of war, as exemplified by his explanation of how changes in military technology had made modern warfare more horrible. Milton asserted that gunpowder weapons (especially those called great ordnance in the seventeenth century) were invented by Satan, composed of substances dug deep from within the bowels of the earth, and shot from a distance for the purpose of punishing man for his sins. ${ }^{51}$

Samuel Daniel, an Elizabethan predecessor of Milton, had also lamented the baneful effect of missile and gunpowder weapons on warfare. Although 
Daniel is said to have had pacifist leanings, his epic poem The Civil Wars, which was about the Wars of the Roses, complained that face-to-face combat had grown less frequent, warfare had become shrouded in anonymity, and no one could say who had killed whom or had performed valorous deeds. Ordinary peasants could now kill nobility. Daniel attributed the intensification of wars to the introduction of the new weapons and the invention of printing, which he thought had caused the dissolution of Christendom by introducing "impious contention and proud discontents." This he blamed on "fierce Nemesis, mother of fate and change, sword-bearer of th'eternal Providence."52

The political philosophy of the English classical republicans enabled them to justify rebellion against tyrants, and they had no difficulty in identifying the tyrant when explaining the origins of the English civil wars. James Harrington argued that the Tudor and early-Stuart monarchs, by neglecting the nobility and allowing that class to become less powerful both politically and militarily, contributed to a collapse of royal government that caused the civil wars: "wherefore the dissolution of this government caused the war, not the war the dissolution of government." "Of the king's [Charles I's] success with his arms it is not necessary to give any further account, but that they proved as ineffectual as his nobility. But without a nobility or an army ... there can be no monarchy." 53 This raises the question whether a feudal army led by the nobility, would have been useful in the civil wars or whether a reformed militia could have saved the monarchy. The classical republicans placed more faith in militias than actual historical examples of such forces would warrant. Nor were the king's armies as badly served as Harrington seems to imply. Officers and other ranks from the British Isles who served in the various armies that fought in the Wars of the Three Kingdoms frequently had already acquired much knowledge and experience in the dynastic and religious wars of mainland Europe. ${ }^{54}$

Perhaps the most radical feature of Harrington's Oceana was its assertion that the bedrock of all government was the exercise of the sword, which allowed the people, through the instrument of the New Model Army, to overthrow the monarchy and nobility. Harrington insisted that the transfer of power was perfectly natural and did not depend on providential intervention. Therefore, it was justified by natural law. The emergence of an army during the time of the English Republic led to increased democratic agitation on the part of junior officers and ordinary soldiers, which despite Harrington's secularism, 
was sometimes justified in terms of a covenant with the Lord God. The exercise of arms by the members of the New Model Army promoted political awareness and activism that gave them the means to achieve their goals. ${ }^{55}$

One of the limitations of the standing militia advocated by Harrington in his Oceana was that it was based solely on the tenure of land. Although Harrington had served in an English regiment of the Dutch army, he had no understanding of political societies, such as the Netherlands, which rested largely on trade. Because the Netherlands and Venice preferred to have their citizens contributing to economic productivity by working at their trades, both of these republics employed armies that were largely composed of mercenaries rather than citizen-soldiers. ${ }^{56}$

John Milton employed religious imagery in Paradise Lost to launch his attack on the bellicosity found in many of the books read by the gentry and the citizens of early seventeenth-century England, yet his justification of the removal of the king and the establishment of the Commonwealth employs the secular vocabulary of English classical republicans. Milton became the secretary for foreign tongues in the Council of State of the Commonwealth in 1649, which made him, in effect, the chief propagandist of the new republic. Going beyond Protestant theories of resistance, Milton's justification for removing tyrants was grounded in natural reason, and allowed the individual citizen as well as the magistrate to punish tyrants. Thus, Milton rejected the view, dating back to classical antiquity, that the sword of justice belongs exclusively to the magistrate or the prince. Like Grotius, Milton stated that the law of nature granted individuals as well as sovereign rulers and legislatures the right to punish offenses against the law of nature. In effect, Milton is saying that the office of king is elective, and popular assemblies possessed the power to elect them and to remove them. ${ }^{57}$ Moreover, since the power of declaring war was always in the power of Parliament, Milton says that it was unlawful and without precedent for the king to make war on Parliament. ${ }^{58}$

Milton's views on tyrannicide could hardly promote peace or stability. He could see no difference between a foreign tyrant such as the king of Spain, who had attempted to invade England, and a domestic tyrant, such as Charles I, who made war on his own subjects. Milton employed Cicero's characteristically Stoic argument that all participated in the brotherhood of man, and that tyrants, whether foreign or domestic, had cut themselves off from that brotherhood. 
Having, so to speak, placed themselves outside the pale of civilization, a tyrant was no better than "a Turk, a Saracen, a heathen." Moreover, by abolishing the distinction between resisting a foreign invader and overthrowing a domestic tyrant, Milton eliminated the distinction between external war and civil war because the individual citizen need not wait for the inferior magistrate to take the initiative in resisting a domestic tyrant. ${ }^{59}$

Marchamont Nedham, like his friend Milton, was another propagandist for the Commonwealth government. A journalist who changed sides in the civil conflicts more than once, he was hired to write for the official journal of the Rump Parliament, the Mercurius Politicus, whose purpose was to defend Cromwellian policy and to celebrate the military and naval achievements of the English Republic. Nedham also wrote a long pamphlet entitled The Case of the Commonwealth, Stated, which was intended to reconcile royalists to the commonwealth. He stated that all governments went through cycles of birth, glory, and death, and ultimately, all perished regardless of merit. All governments, good or bad, rested on "the power of the sword"; this had been "the foundation of all titles of government." Thus, whether the commonwealth's acquisition of power from the monarchy was legitimate or not, was a question that was quite irrelevant. Nedham reminded his readers that the English monarchy was historically based on the right of conquest, and thus, was no different from the English Republic. ${ }^{60}$

Algernon Sidney, perhaps the most bellicose of all English classical republicans, thought a rebellion now and then was not a bad thing: "Civil tumults and wars are not the greatest evils that befall nations." In response to Sir Robert Filmer's assertion that more men died in civil conflicts under "popular governments than in absolute monarchies," Sidney replied that it was worse for nations to suffer "misery, weakness and baseness" because they lacked the courage and strength to contend for a better life. Turning Calgacus's speech as recorded in Tacitus's Agricola upside down, Sidney said that failure to fight for liberty gives "the name of peace to desolation." No state can be entirely free from civil wars and tumults, but republics were less troubled by such contentions than monarchies because merit will advance men of wisdom and courage to lead the commonwealth. ${ }^{61}$ Filmer had asserted that rebellion was a sin comparable to witchcraft. While individual men are obliged to obey the commands of the magistrate, Sidney replied, "The general revolt of a nation 
cannot be called a rebellion," and "rebellion is not always evil." Whether seditions, popular tumults, and civil wars are just or unjust is to be determined by whether a government works to preserve liberty or not. This principle derives from Grotius's concept of a just war between states, but Sidney applied the principle to the internal affairs of a state. ${ }^{62}$ There is no government in the world that can provide a guarantee against sedition and civil war. Such popular resistance will always be justified as long as magistrates exceed their authority or powerful people break the laws of the commonwealth. For these reasons, the threat of popular violence is always necessary to preserve republican liberty. ${ }^{63}$

"Mixed and popular governments," Sidney thought, also "preserve peace and manage wars better than absolute monarchs." The latter were dependent on mercenary soldiers who served only for wages and "often betray their masters in distress, and always want the courage and industry which is found in those who fight for their own interests, and are to have a part in victory." Sidney stated that the examples of ancient Greece and Rome demonstrated the wisdom of having citizens fight wars abroad to preserve liberty at home, but also to teach them by the constant exercise of arms to be valiant. An expansionist policy based on trade was compatible with these goals as long as the wars were fought by citizen-soldiers and not mercenaries. ${ }^{64}$

\section{Hobbes's fear of civil strife}

Whereas Algernon Sidney thought that an occasional foreign or civil war kept the citizens of a commonwealth in a warlike stance and ready to defend republican liberty, Thomas Hobbes labored to discover a science of peace. Hobbes had a particular horror of civil war because he had observed the effects of internal strife both in the British Isles and while residing in France, but he had also learned from Thucydides the lesson that internecine strife was the most usual cause of the demise of city-states. Hobbes further thought that domestic conflict invited foreign aggression. At the conclusion of the English civil wars, Hobbes, like other Englishmen of the time, was disposed to support whatever regime held power because of a desire for peace and a continuing fear that the civil wars would revive. Although he would have preferred a 
legitimate royal government, Hobbes was prepared to support the Cromwellian regime, and consequently, returned home from France and swore the Engagement Oath pledging loyalty to the lord protector. His justification for this action may be found in the "Review and Conclusion" of The Leviathan, in which he states that a soldier was obliged to adhere to his military oath of loyalty only so long as his army "keeps the field and giveth him means of subsistence." Thereafter, the soldier might swear allegiance to whomever offered him protection. ${ }^{65}$

The causes of interstate and civil wars arose not so much because people desired such conflicts, but because men are "ignorant of the causes of wars and peace," and have neglected to learn their responsibilities for preserving peace by practicing the principles of moral philosophy that derive from natural law. For Hobbes, moral philosophy consisted of a set of "laws of nature," which sought self-preservation and promoted peace. These could be discovered by the use of reason, but Hobbes admitted that they were not universally recognized because "the violence of their passion" and "evil custom" often led men in another direction. ${ }^{66}$

Hobbes thought that the fundamental causes of wars were to be found in the diversity of opinions of individual people rather than the differing interests and policies of states. These threats to peace erupted from the excessive ambitions of individual politicians who risked plunging their countries into factionalism, sedition, and civil war. Such ambitions could spill over into imperial adventures abroad, or tempt hostile foreign states to intervene in a country suffering from weakened government. Although Hobbes was more concerned about the dangers presented by seditions and civil wars, he did have certain assumptions about the causes of interstate wars. These were largely caused by dynastic ambitions and rivalries, and by disagreements about religion. In the latter case, loyalties transcended national identities based on language, culture, and history, and challenged allegiance to a particular royal dynasty in which it was believed that a conflict existed between the obligation to obey divine commands on the one hand, and the duty to remain loyal to one's sovereign on the other. Hobbes thought that the best way to calm religious passions was to suppress all theological beliefs except belief in the divinity of Christ. This rather impractical solution depended on an Erastian church-state relationship in which the clergy of an established church continually reiterated 
the necessity of obeying all the laws and commands of a sovereign monarch. A secular state with religious toleration would have been unthinkable for Hobbes, who could not conceive of a legitimate diversity of interests occurring within a stable society. ${ }^{67}$

Hobbes was appalled by the way that differing religious opinions led to civil strife. This confirmed his strong belief in a religion established by law in which preaching was licensed and carefully controlled. Among those whom Hobbes blamed for popular disloyalty to Charles I during the civil wars were the clergy of the Church of England-especially those of the presbyterian party who still generally remained within the Anglican Church before 1640. In their sermons, they pretended "to have a right from God to govern every one in his parish, and their assembly the whole nation." Hobbes thought that the clergy of the Church of England-both those who taught in and governed the universities as well as the bishops and those who served in the parishes-had arrogated to themselves the power of the Catholic popes and bishops, which the Henrician Reformation had abolished. This power of ecclesiastical government properly belonged to the king, Hobbes insisted, but the clergy had come to claim this divine right for themselves. The clergy pretended to be learned in divinity, which they confounded with religion. Hobbes denied that the Church of England or any established church possessed political authority over a sovereign ruler, but he did concede that the clergy of such a church should be listened to, and that a sovereign might find their pronouncements persuasive. ${ }^{68}$

Hobbes was a philosopher with a European-wide reputation, but he was not appreciated at home where he was unjustly accused of atheism, which in the seventeenth century meant heresy. This was because he ignored the spiritual dimension of religious life and advocated mechanistic philosophy. He was later considered a deist. The latter accusation was perhaps not entirely unfair, since he wished to make ethical behavior and not religious beliefs the test of loyalty to the established church. Hobbes wanted an established religion that deemphasized individual conscience, took away the church's right to insist on a correct interpretation of the scriptures, abolished clerical power, and merely insisted on moral behavior. Hobbes was not prepared to allow freedom of speech or unregulated preaching because to do so would abandon the power of controlling public discourse, which properly belonged to the sovereign. When men make a covenant by means of civil laws to form a commonwealth, 
said Hobbes, they agree to impose on themselves a restraint on speech so as to avoid contention, and this is especially necessary in the matter of religion in which disputes are most likely to occur. ${ }^{69}$

One contradiction in Hobbes that is difficult to explain is his fear that religious controversy might disturb the peace of the commonwealth and infringe on the authority of the sovereign as the head of church and state, while at the same time, he continued to cling to an independence of thought in religious matters that others interpreted as "atheism," or more properly, heresy. A royalist by preference, for twelve years, Hobbes had lived abroad, mostly in France, where he had a wide circle of admirers. Although his works were banned by both Catholic and Protestant authorities in mainland Europe, they were still possible to obtain in different translations, and they were widely read. ${ }^{70}$

Hobbes blamed both the clergy and members of Parliament for failure to instruct the people of England concerning the obedience that they owed to their king. He believed that it was obedience that held together political societies: "Take away in any kind of state the obedience (and consequently the concord of the people), and they shall not only not flourish, but in short time be dissolved. And they that go about by disobedience to do no more than reform the commonwealth, shall find they do thereby destroy it." ${ }^{\text {"1 }}$ The members of Parliament and the relatively small group of electors who possessed the parliamentary franchise refused to recognize the duty that they owed the king to pay taxes to help raise an army for the common defense at the beginning of the civil wars. This failure to recognize and support the king's authority was widespread, and the voters were inclined to choose members of Parliament who opposed granting taxes to the king. ${ }^{72}$

\section{The science of politics}

In his pursuit of peace, Hobbes had first to construct a science of politics based on natural law and an investigation of the origins of conflict. Hobbes was acquainted with many scientists, and he was conscious that he was working in the midst of a scientific revolution, although his understanding of what constituted science was sometimes imperfect. His own study of natural science 
led him to prefer the empirical over the theoretical approach to knowledge, and to emphasize practice. Hobbes associated prudence with the empirical study of accumulated historical examples. This, in turn, would lead one to sapientia, a kind of moral and political wisdom, which would confer a knowledge "of what is right and wrong and what is good and hurtful to the being and well being of mankind...." These scientific and rational methods of inquiry would lead one to an infallible knowledge of how political society worked, and would help mankind avoid many of the mistakes of the ancient Greeks and Romans. This brought Hobbes into strong disagreement with Aristotle, who placed theoretical science above moral philosophy and the empirical study of political behavior. Hobbes's continuing disagreement with Aristotle led him to denounce that philosopher as "the worst teacher that ever was." ${ }^{73}$ Hobbes thought that ancient authorities such as Aristotle, Cicero, and Seneca had derived their philosophical principles from traditions, customs, and older authorities rather than constructing a more rational and methodical or scientific approach to politics. The uncritical study of Aristotle in the universities had led to the teaching of the rebellious notion "that any lawful sovereign may be resisted under the name tyrant." Only time and a revision of the university curriculum could overcome such seditious notions, thought Hobbes. ${ }^{74}$

When constructing his science of politics, Hobbes insisted on the need to investigate the origins of political society and how concepts of justice had originated. This required doing a kind of dissection of the body politic in order to discover how it was put together and also analyzing human nature in order to understand the nature of social bonds. ${ }^{75}$ Hobbes says that living in a state of nature, before civil societies were entered into, was like living in a perpetual state of war "of every man against every man." War consisted not only of battle, but also of living in a climate of war in which other men had a disposition to offer violence. The consequence was a "continual fear and danger of death; and the life of man, solitary, poor, nasty, brutish and short."76 Thus, Hobbes asserts that the state of nature was characterized by anarchy, and he turns the primitivist Golden Age as described by Hesiod and Ovid (not to mention the Biblical Garden of Eden) upside down and says that it was like living in Hell. Commonwealths, even when they were formally at peace with one another, continued to distrust neighboring states, and felt the need to maintain 
armies and defend their borders. Within commonwealths, individual citizens distrusted their neighbors enough to feel the need to bolt their doors and carry weapons when they traveled. ${ }^{77}$

Hobbes believed that people had been given the gift of reason so that they might discern moral and natural law, which he said was the same thing as divine law. The basic principle of natural law is "the pursuit of peace," which is the essence of divine law. ${ }^{78}$ Men establish commonwealths and agree to place restraints on their individual actions in order to free themselves from "the miserable condition of war." Hobbes thought that men were so prone to fall into disputes about honor, that it was absolutely necessary for the sovereign power to strictly regulate the laws of honor. The sovereign power must not only jealously guard the right to sit in judgment on disputes that could disrupt the commonwealth, but also maintain armed forces to restrain and control the same, or "he retains the judicature in vain, for want of execution of the laws." ${ }^{79}$

Hobbes's views concerning social hierarchy and aristocratic honor changed as his ideas developed. It is only in an earlier work, The Elements of Law (written in 1640 and widely circulated, but not fully published until the nineteenth century), that he regards honor in war to be a virtue. In The Elements of Law, Hobbes states that in ancient times aristocratic virtue had imposed limits on taking lives and booty among the defeated. This concept of aristocratic honor had been the only motive for constraints on methods of warfare, since in time of war the law was silent, as an old proverb supposedly phrased it. Aristocratic honor depended on the recognition by others of the superiority of aristocracy. This, in turn, rested on the exercise of power and a readiness to employ force against those who were not prepared to be "sociable." The problem with the concepts of honor, aristocratic pride and magnanimity, which were all linked together, was that they rested on the notion of social superiority. But Hobbes, in his later writings, came to attach great significance to natural equality of status because it was this natural equality among people as they existed in the state of nature that made individuals vulnerable to the aggressions of others and disposed them to constant warfare. This was actually a rhetorical device that expressed Hobbes's horror of the concept of social equality. ${ }^{80}$ Hobbes rejected the Aristotelian view that there was a natural hierarchy of merit that allowed one to discern the difference between, for example, an aristocrat and a less well born person, or between a free man and a slave. Hobbes insisted that 
the sovereign was the source of all honor-not aristocratic descent. It was pride in descent that made aristocratic quarrels so frequent an occasion of violent conflict. Hobbes wished to promote the view that it was a universal consent on the part of everyone to live in peace and acknowledge that it was the authority of the sovereign that held political society together. ${ }^{81}$

The thirst for revenge and factionalism presented two threats to the maintenance of peace in a political society. To seek revenge for past injustices is in accord with natural law, provided that one does so with an eye to the future. To seek revenge only for past wrongs without being willing to forgive is mere vainglory and contrary to reason. To hurt another without cause is to risk providing one's enemy with the pretext for war. Insulting words are fighting words that readily lead to violent conflict, because men in a traditional society would rather die than suffer reproach or insult. It is therefore contrary to natural law to offer reproach because it sows discord..$^{82}$ Factionalism, or the defense of particular rather than common interests, can also lead to civil conflict or exposure to foreign wars. Popularity is another kind of faction, and often rises from mischief procured by men "of immoderate private wealth" who pursue their own ends rather than the common good. It is the duty of rulers to break up factions because to allow them to continue is like admitting an enemy within one's defensive walls. Factionalism, fanned by the eloquence of ambitious orators, can also lead to civil wars or worse. ${ }^{83}$

Hobbes thought that absolute monarchy represented the best means of calming the passions and factionalism that led to violent conflict, yet he was enough of a realist to understand that absolute rulers with no limitations on their power and who were also subject to the same defects as other mortals, made wars seem inevitable.

In all times, kings and persons of sovereign authority, because of their independency, are in continual jealousies, and [in] the state and posture of gladiators, having their weapons pointing and their eyes fixed on one another; that is, their forts, garrisons and guns upon the frontiers of their kingdoms, and continual spies upon their neighbours, which is a posture of war....

To this war of every man against every man, this also is consequent: that nothing can be unjust. The notions of right and wrong, justice and injustice have there no place. Where there is no common [i.e., international] power, 
there is no law; where no law, no justice. Force and fraud are in war the two cardinal virtues.

While some might argue that war can unite a political community, Hobbes would reply that with the conclusion of war domestic factions will once again become dominant. ${ }^{84}$

There was always an ambivalence in Hobbes about whether human nature was universally disposed to war. Hobbes did not believe that men were evil by nature; he thought that fear was the basic cause of war. Some men were more aggressive than others, but fear was still the main cause of war, even when they launched preemptive strikes. ${ }^{85}$ Certainly, his study of Thucydides' thoughts, occasioned by his translation of Thucydides' History of the Peloponnesian War (1628), which was Hobbes's first important piece of scholarship, brought out the pessimistic side of Hobbes's ambivalence. Hobbes learned from Thucydides that war, with its attendant problems of compulsory military recruitment, dearth, disease, and mortality, broke down the bonds of human society, creating stasis, or civil conflict. The Peloponnesian Wars, Thucydides concluded, were more than merely a civil war of Greek states fighting other Greek states that nearly destroyed the Golden Age of Greece, but at a different level, constituted a war "of every man for himself against everyone else." Thucydides had concluded that war had become a "condition of human nature." 86

Hobbes's interest in Thucydides may have been prompted, at least in part, by an interest in finding an antidote to Tacitus's insistence on equating the government of kings with tyranny, as well as the recognition that Tacitism, as promoted, for example, by Justus Lipsius and his writings about Tacitus, provided a set of ideas espoused by swordsmen as well as classical republicans. In England, as Hobbes would surely have noticed, the study of Tacitus was associated with the circle of Robert Devereux, second Earl of Essex, who showed a keen interest in the events that had led to the overthrow of Richard II. Essex himself led an abortive rebellion at the end of Elizabeth I's reign because of his discontent with her policies such as peace with Spain. The members of Essex's circle constituted a war party, which believed that peace at home was best procured by continuing the war with Spain. ${ }^{87}$ Hobbes's experience of translating Thucydides' History of the Peloponnesian War made 
him aware not only of the need to pursue peace, but also left him skeptical about aristocratic and democratic participation in government. He believed that the bellicose aspects of classical republicanism would bring only instability and endless civil strife. ${ }^{88}$

Paraphrasing Thucydides, Hobbes states that the main causes of civil war were fear concerning security, a desire for honor and glory as well as profit: "Men compete for honour and dignity ... hence men experience resentment and envy, which are sources of sedition and war...." ${ }^{\prime 9}$ The vain seeking after rank and precedence was something that Hobbes thought characterized the public assemblies in the ancient world that he associated with aristocracies and democracies; he thought monarchy gave less scope for the expression of such passions. "Man's tongue is a trumpet to war and sedition; and it is said that Pericles once made thunder and lightning in his speeches and threw all Greece into confusion." 90

Just as Thucydides thought that the overheated rhetoric of demagogues was one of the causes of the Greek civil wars, Hobbes, in his translation of Thucydides, saw a parallel with the confrontational politics and inflammatory speeches of politicians in the Caroline Parliaments of 1625-28, and also saw a reflection of the dangerous influence of classical republicanism. It was difficult to avoid the conclusion that more temperate speech would promote more political stability. Yet, Hobbes noted that any orator who spoke with restraint was thought to be a coward-both in Athens and in Charles I's Parliaments. Hobbes offered the opinion that there were few wise men in the Caroline Parliaments because wise men knew how to get business done without resorting to eloquence. ${ }^{91}$

Turning from Greek to Roman history, Hobbes used the example of Catiline, who had been the instigator of the most serious rebellion during the Roman Republic, as depicted in Sallust, to demonstrate the danger of a demagogue who was possessed of eloquence, but not wisdom. Such rabble-rousers always pose a threat to the peace because they are adept at stirring up the passions of the people. Their arguments are rhetorical rather than logical, and are devoid of wisdom or acquaintance with factual analysis. One cannot be said to be possessed of wisdom unless one understands "the rules of justice and injustice, honour and dishonour, good and evil" together with a knowledge of "what achieves and preserves peace among men and what destroys it; what is one's 
own and what is another's..." Fake eloquence always makes a good situation seem bad, or a bad situation seem worse. Such orators are skillful in employing eloquence to appeal to the raw emotions of the members of a popular assembly rather than their rational faculties. The purpose of their eloquence is to persuade rather than to teach. Because all political societies are devised by the hand of man, they are impermanent and must inevitably collapse. Thus, they are especially vulnerable to discontented individuals who see the chance to change their circumstances by employing their oratorical abilities to start a rebellion, which often leads to civil war. Since rebel leaders usually possess more eloquence than wisdom, they fail to understand that rebellions rarely succeed..$^{92}$

\section{Political psychology: The science of peace and absolutism}

Thucydides' use of what modern social scientists call political psychology very much influenced how Hobbes went about writing his Leviathan, which sought to examine people's motives for going to war in universal terms. Hobbes assumed that human nature, in all periods of history and throughout the world, remained the same. In order to achieve peace, one must study war as a phenomenon, but this must also be preceded by an attempt to analyze humans in a state of nature. Here, there existed such a threatening climate of war that people were reluctant to undertake the industrial arts, dared not venture on commerce, did not engage in agriculture, nor undertake the arduous task of cultivating knowledge because the future prospects were so dismal. Men neglected to form social bonds because they lived in fear of death. The similarity of Hobbes's description of the perpetual climate of war, where one could not imagine a state of peace, was derived from Thucydides' History of the Peloponnesian War. By painting such a dark picture of the persistent clouds of war that enveloped men living in a state of nature, Hobbes's rhetoric aimed at focusing attention on how to seek self-preservation, avoid civil wars and wars between nations, and how to pursue peace. Hobbes saw Thucydides depicting the Athenians as a people of passion perpetually in motion, reckless in their oratory, always ready to go to war, unwilling to allow other people to live in peace, and "fatally self-destructive." ${ }^{3}$ 
Because Hobbes is usually thought to hold the view that mankind is, by nature, involved in a perpetual war in an insecure world in which concepts of morality count for naught and only coercive power commands obedience, he is usually regarded as a realist. In internal politics, his abhorrence of civil conflict is so great that the individual's rights are surrendered to an absolute ruler. Although Hobbes has less to say about this struggle when applied to relations between states, it is widely assumed that he was a realist in this sphere also. Yet, an argument can be made that Hobbes sought to develop a science of peace to pursue this seemingly elusive goal. Hobbes insisted that the prescription was simple: Men need only obey their rulers and the laws granted by them and listen to the judges who interpreted those laws, and they would find themselves on "the highway to peace." But they must not listen to those philosophers who tell them that they may rebel against and overthrow those so-called tyrants who had been set to rule over them. ${ }^{94}$

Hobbes states that it is a fundamental law of nature to work for peace as far as possible. This is based on the premise that a person should avoid anything destructive of his own life, which means that he should avoid becoming involved in conflicts in which he might lose his life. This requires that everyone yield the right to protect himself by force to the state, which then acquires the right to protect everyone collectively. It is only when one has failed to secure peace that one may justly pursue war. Hobbes's interpretation of natural law assumes that men will first attempt to bring about peace within domestic society before pursuing international peace. ${ }^{95}$ While all men seek peace, they do so by different paths because of a diversity of opinions, which can be made manifest by a condition of perpetual warfare, but that does not mean that they are not seeking peace as a future goal. Since it is only reasonable to pursue peace as a future goal, it follows that the path that men should follow in seeking peace is to practice good manners. Good manners, in this sense, refer not to social conventions "or such points of small morals," but to those larger principles of moral philosophy that are based on virtues discoverable in the laws of nature. These include "modesty, equity, trust, humanity, mercy. ..."96

Clearly, Hobbes was not prepared to accept Thucydides' belief in the inevitability of war. He believed that it was possible for a commonwealth to achieve peace through a demonstrated record of having the means to defend itself, and through the discouragement of political ambitions that might lead 
to foreign adventures and imperial expansion. Because Hobbes thought that the exercise of liberty in the public sphere had led to intemperate speech and threatening rhetoric, his first step toward establishing a science of peace was to insist that the exercise of liberty in the Greek sense had to be surrendered. Demagogues could not be allowed to use inflammatory rhetoric to urge military adventures, and counselors who advised prudence and restraint should not be called cowards. This, it goes without saying, was a solution that was incompatible with a parliamentary system that allowed room for aristocratic or democratic participation. Absolutism remained the only choice. ${ }^{97}$

The seventeenth century-especially the 1640 s and the 1650s-saw numerous aristocratic and popular rebellions in various parts of Europe, and it is not surprising that Hobbes and his contemporary James Harrington were both driven by a desire for peace. Harrington believed that the best path to peace was to have a republic in which the laws were enacted by a popular assembly such as the English Parliament. However, he admits that this form of government is fraught with danger. There was an inherent risk that such a popular assembly would be subject to factionalism and vested interests in both the selection of representatives and in the ways in which legislative business was conducted. The people were often "careless" and "tumultuous"; the clergy were the "declared and inveterate enemies of popular power"; the lawyers pursued their own "private interest point-blank against the public"; men with too much wealth and land tended also to pursue their own interests, while the tendency, on their part, to retain a monarchy was a distraction. Harrington thought that plain gentlemen who did not possess the "great estates of noblemen," but rather enjoyed "a good honest popular estate" which was heritable, would have no interest in establishing or retaining a monarchy, but would naturally incline toward a commonwealth characterized by popular participation in the civil administration on the part of those who served or had served in the militia. As in the Swiss cantons, electoral rights were conferred only on those who performed military service. Having learned discipline during their military service, the civil officers, serving as sheriffs, magistrates, and elected representatives, would be able to govern and achieve "perfect reformation by degrees and without violence." Hobbes, of course, had abolished civic participation altogether. Harrington agreed with Hobbes that natural law requires peace, and this, in turn, necessitates obedience to man-made or positive 
law. Harrington preserved a ritualized participation in government, which, says Jonathan Scott, was obligatory, but was devoid of any substance or choice.98

Hobbes rejected the notion that sovereignty could be divided or limited. In effect, he said, as far as this principle applied to England at the beginning of the civil wars, that sovereignty rested in the king-sole, not the king-in-Parliament. This doctrine assigned to Parliament only an advisory role. Thus, it was the king alone who possessed the authority to declare war and to wield "the sword both of war and justice". The king-sole possessed the power to make all laws, decide all controversies, and command the militia; his subjects had no right of resistance to these actions. Hobbes also insisted that the king's subjects could not refuse to pay taxes that the king had levied. This quite explicitly denied the theory of possessive individualism or the absolute and unqualified rights of private property that was coming to be widely accepted in the seventeenth century. Such views about the absolute nature of sovereignty would have found acceptance only among high royalists, but then, Hobbes spent much of his life in the rarefied company of aristocrats. ${ }^{99}$

Subsequently, in his Leviathan, Hobbes admitted that the possession of goods and land was a natural right that the subject possessed, but he made it dependent on the exercise of sovereignty by the ruler. The possession of such goods and land was likely to lead to perpetual conflict, and only a strong government in the hands of a sovereign with unlimited power could protect subjects and allow them to enjoy their property rights. Coercive power, without force, cannot uphold sovereignty and protect such natural rights. ${ }^{100}$

Another power that pertained to a sovereign ruler was "to be a judge of what opinions and doctrines are averse and what conducing to peace"; it followed that a ruler might suppress those opinions and doctrines that were likely to disrupt peace and concord. Agents of the ruler should be appointed to censor all books before they are published. Hobbes does concede that through unskillful government or the teaching of false doctrine, a truth could disrupt a society and possibly lead to war, but the fault lay with those who governed ineptly or taught false doctrines because they were careless about preserving peace, and consequently, lived in a state of undeclared war. ${ }^{101}$ Hobbes believed that all civil and moral philosophy before his time inculcated error because all moral opinions and their political implications could be disruptive. His solution to this problem was to confine all political activities to the sphere of 
the sovereign, and to limit his subjects' intellectual activities to private life and to teach them not to meddle in the sovereign's affairs. The concept of a legitimate command or a just war derives from the legitimate authority of the ruler. Private men who presume to pass moral judgment on political matters are "aspiring to be kings." A commonwealth could not be expected to remain stable where subjects laid claim to moral judgment in political matters. ${ }^{102}$

Charles II would have agreed with Hobbes about the sovereign power of censorship. The restoration of the monarchy and the re-institution of press censorship made it difficult to discuss the recent civil wars because Charles II was determined to prevent a revival of the bitter controversies that surrounded those conflicts. Royal control of the press was something that he took a personal interest in, and he sometimes read proposed books in manuscript before allowing publication to proceed. He read the manuscript of Hobbes's Behemoth, in which Hobbes discussed the origins and causes of the civil wars, and consequently, that book was not published until 1682, after press censorship had broken down during the Exclusion Crisis of $1678-81 .^{103}$ One wonders if Hobbes understood how inflammatory some of his own remarks must have seemed. In his Behemoth, he charged that the citizens of London and other centers of trade in England had envied the prosperity of the people in the Netherlands after they had thrown off the rule of the king of Spain, and thought that they might achieve the same commercial prosperity by rebelling against their own sovereign. Since Charles II's government continued to be very dependent on the City of London for loans, banking services, and assistance in collecting the customs and excise duties, the king could hardly have been pleased by Hobbes's analysis. ${ }^{104}$ While many Englishmen were troubled by Hobbes's advocacy of political absolutism, the French, following their experience of the Fronde and its myriad attendant blood-feuds, welcomed his political theories justifying absolutism, which were based on and accorded with a French Neo-Stoic tradition dating back to Montaigne. ${ }^{105}$

Hobbes was a well read classical scholar, and except for his Behemoth, he drew most of his examples used for illustration in his principal works from ancient authors. This led to a pronounced distrust of the ancients. Hobbes thought that exposure to the writings of Greek and Roman authors without "the antidote of solid reason" and the corrections "of discreet masters" instilled in young men in the Three Kingdoms harmful ideas such as love of martial 
glory, a disposition to war, a fondness for popular government, and a tendency to view kings as tyrants, which could easily lead to rebellion and civil war. Some of these men found their way into the House of Commons, where they stirred up trouble with their eloquence. ${ }^{106}$

The famous deeds and sayings of the Greeks and Romans have been commended to history not by reason, but by their grandeur and often by that very wolf-like element which men deplore in each other; for the stream of history carries down through the centuries the memory of men's varied characters as well as their public actions. ${ }^{107}$

In classical Greece, observed Hobbes, aristocratic and democratic factions in neighboring city-states caused discontent within the states that were ruled by kings. So also, the imitation of political principles and practices observed in the Dutch Republic aroused a love of novelty that bred discontent in early Stuart England.

One of the reasons why Hobbes rejected the political philosophy of the ancient Greeks and Romans is that they derived their principles, not from nature, but from customs of their city-states, which had a long history of being unstable and perpetually at war. The turmoil that resulted not only led to civil strife, but also caused their leaders to favor a policy of expansionism that involved citizens in foreign wars and occasioned the exaltation of the exercise of arms and military glory. In short, Hobbes thought, "the learning of the Greek and Latin tongues" produced a legacy in the Western world of "tumults" and "the effusion of much blood." The moral philosophers of the past had been wrong; they had departed from moral law and their teachings had led to a state of perpetual war. They failed to seek out the universal principles of moral law, and instead, merely codified the customs of their society and culture. These are among the reasons that Hobbes cited when he laid part of the blame on the universities for contributing to the outbreak of the civil wars. ${ }^{108}$

\section{Inventing peace}

Sir Henry Sumner Maine thought that "war appears to be as old as mankind, but peace is a modern invention." However, the longing for peace and the revulsion against war have a long history. Such attitudes were often expressed 
in religious terms-especially in the Middle Ages. The Age of Reason did not invent such attitudes; it merely secularized them. Because the Old Testament legacy of sin was war, St. Augustine of Hippo could imagine peace only in the next life and only for those who would be saved. Those who followed him had such small expectation of longevity that they doubted whether they would live long enough to pursue peace in this world. In our own age, fewer people believe in an afterlife, but the threat of obliteration by nuclear weapons makes the cause of permanent peace seem more urgent. ${ }^{109}$

Peace must always be a "contested concept" because every participant in a war will always have different objectives in sight when starting a war or negotiating a peace settlement. A peace that is dictated after a crushing victory can hardly be acceptable to the losing side. The defeated may obtain a release from the hardships and suffering that accompany war, but otherwise will gain little by the peace accord. Victors have been known to impose punitive peace settlements that burden the vanquished with unacceptable forms of government, and which sow the seeds of future conflict unless ameliorated by some strong and impartial form of international government. Unless all parties to a peace settlement participate on equal terms, there can be little prospect for permanent peace. ${ }^{110}$

Throughout the Middle Ages, learned men-mostly clergy- recognized that war was a legitimate and just activity. Not until the very end of that period did the Erasmian humanists begin to argue that war was not "a significant part of the natural or divine order." They began to imagine a social and political order from which war had been banished, but they were able to do so only by degrees and on a small scale. Any scheme of universal and permanent peace must necessarily be fragile. It takes generations to build such a political and social order, but as long as sovereign states, which have the recognized power to make war, still exist, such a scheme of universal peace could be destroyed in short order. Peace, as Sir Michael Howard has observed, is an ideology—and a recently invented one at that. It is in the nature of ideologies to simplify the truth. War is also an invention of man, but it is very much older than pacifism, and has long since been institutionalized. ${ }^{11}$

Most of the proposals for universal and perpetual peace in the Age of Reason and the Enlightenment were based on principles laid down in the writings of Grotius and Hobbes. Some of these later political and moral 
philosophers, such as Immanuel Kant, were in general agreement with the Hobbesian view of man in the state of nature; others, such as Samuel Pufendorf, rejected those views. This influence can be attributed to Hobbes's tendency to be a more skeptical philosopher than Grotius had been, which enabled him to be a greater advocate of peace than Grotius. ${ }^{112}$

Hobbes had allowed that all individuals had a natural right to decide when they needed to defend themselves from grave danger, but he insisted that, at some point, they must surrender that independent judgment and agree on a common means of defense. When Hobbes discussed the turmoil and violence that was found in the state of nature, he stated that he was thinking more of interstate relations than the relationship between individuals. Just as individuals did well to surrender their natural right of self-defense to a sovereign ruler or a leviathan, Hobbes also thought that since sovereign rulers were always contemplating war with one another, even during those times when they were not actually engaged in hostilities, it made sense for those rulers of sovereign states to submit to the authority of a single sovereign ruler. ${ }^{113}$

The Enlightenment presented a much more serious challenge to church and state than did the Reformation. While the Protestant Reformation caused a division in Christendom, none of its confessional positions challenged the basic tenets of Christianity, nor were the assumptions of monarchy, aristocracy, and the sources of religious authority questioned (except, perhaps, papal authority). What was called "Cartesianism" appeared in the middle of the seventeenth century and introduced rationalism and secularism, which challenged the fundamentals of all revealed religions, the authority of the Bible, Aristotelianism in philosophy, the accepted principles of politics and the assumptions about nature and the universe. It ushered in mechanistic principles of science and repudiated divine causation. ${ }^{114}$

Benedict Spinoza is regarded by some as the thinker who did the most to undermine the philosophical basis of revealed religion, traditional ways of thinking, morality, and political authority based on divine right. He is often compared to Hobbes in his attack on the old intellectual order, but Hobbes insisted that Spinoza was much more radical than he. Spinoza was an atheist and a materialist who not only rejected Divine Providence, but could see no external creator beyond a mechanical universe. He was expelled by his own synagogue when he was only twenty-three years of age. Hobbes, by contrast, 
remained more conservative in his political views, insisting on the need for a strong ruler to preserve the political and social order as well as a state church to regulate moral behavior, even if his own personal religious opinions were less than orthodox. ${ }^{115}$ Spinoza's philosophical writings, to a considerable extent, are commentaries on the moral and political philosophy of Hobbes-especially as they were applicable to the Dutch Republic. Unlike Hobbes, who believed that outward conformity to a church by law established was necessary for a stable political society, Spinoza was an advocate of religious toleration. He could see that the policy of religious uniformity had failed in England, and he favored the practice of toleration that had attracted Iberian Jews, among whom were numbered his ancestors, to the Netherlands. Subsequently, the political influence of the Calvinists largely undid the policy of toleration in Holland and other of the provinces of the Netherlands. ${ }^{116}$

Spinoza thought that men as individuals are prone to anger and envy to a high degree, and are therefore natural enemies of one another: "For he is my greatest enemy whom I need most to fear, and against whom I have most need to guard myself.' Once man realizes that there is anarchy in the state of nature, he seeks to cling to others and form a society for protection, and thus, to preserve peace. Spinoza has effectively reformulated Hobbes's question: How can a state be constructed that will provide men with the maximum peace? Peace is not the mere absence of war, nor can it exist merely through apathy; it must be based on a concept of what is good for the commonwealth. A political society whose subjects are constrained from civil wars or rebellions may be free of war to a degree, but they do not enjoy peace. Peace is best secured where a number of commonwealths enter into peace treaties with one another-the more which do so the more likely they are to observe the conditions necessary for peace: "concerning peace it can decide nothing, save with the concurrence of another commonwealth's will. Whence it follows that the laws of war regard every commonwealth by itself, but the laws of peace regard not one, but at least two commonwealths, which are therefor called the contracting powers." 117

The main purpose of the state was to provide peace and security for its citizens. This was best achieved by promoting harmony, and the ideal form of government for accomplishing this was a democratic republic. By contrast, a political society that fails to provide harmony-where crime and internal disorder prevail-differs little from living in the original state of nature. The 
form of government most likely to give rise to internal disorder and to engage in war was a monarchy. The only way to ensure that a monarchy would avoid these evils was to oblige the monarch to consult a large council of citizens elected not for life, but for specified and limited terms of office. A strong state requires the participation of its citizens; a political society whose citizens are apathetic resembles nothing so much as a "desert." This would minimize the dangerous influence of the courtier interest, which has always tended to erode royal power and enhance aristocratic interests-especially when the king was a child or otherwise impaired. The greatest danger to peace and the public good occurs where kings possess complete control of an army made up of foreign mercenaries or professional soldiers. Indeed, employing mercenaries or professional soldiers was to lay "the foundations of eternal war." The way to prevent this was to have a citizen army whose officers and commanders were not paid salaries, but served out of a sense of duty. Clearly, Spinoza had little respect for the kind of monarchy found in early modern Europe. ${ }^{118}$

In Spinoza's opinion, a stable state was one that was just powerful enough to preserve its own possessions without coveting those of another state. Such a state will do "its utmost to avoid war and maintain peace." Spinoza reveals Machiavelli's influence here when he insists that his model commonwealth would be sufficiently strong so that no other state would desire to attack it, but not so strong that other powers would fear it. Spinoza's model commonwealth closely resembled the Dutch Republic, which he thought had a bias toward peace. The reason that Spinoza believed that rulers and magistrates had a strong obligation to avoid war and protect trade is not difficult to ascertain. His family's mercantile business had been ruined by losses and debts resulting from their ships and cargoes being seized by the Barbary pirates and by English warships during the Anglo-Dutch Wars. Although he was a republican in his political thought, he was no friend of Oliver Cromwell or the English republicans. ${ }^{119}$ Spinoza anticipated the problem of vested military and defenserelated interests, which make it difficult to avoid military adventures and remain at peace. In his model commonwealth, Spinoza specified that the salaries of his "senators" should be derived from import-export duties on the assumption that foreign wars always disrupt trade. Additionally, he specified that members of the legislature could not hold positions of command, or indeed, perform any military duties, and could not look forward to sharing in 
the spoils of war. Thus, Spinoza hoped that legislators would have more to gain from peace than war, and would never attempt to prolong a war. He thought that wars should only be waged to secure peace, and when an enemy city was captured it should not be retained and garrisoned. But if an enemy city once captured refused to accept the terms of peace offered and was thought to pose a future threat, it should be destroyed and its inhabitants moved elsewhere. ${ }^{120}$

In contrast to Spinoza, the North-German philosopher Samuel Pufendorf rejected Hobbes's view of the state of nature as utter savagery; he believed that the natural order could be better characterized by peace, in which individuals, under the guidance of God, sought to build a better society. Pufendorf, like a number of North-German men of learning, was in the employ of the Swedes, and distrusted the belligerent and expansionist views that characterized the writings of many English and Dutch thinkers. Pufendorf saw the German attempt to build a more peaceful order following the end of the Thirty Years War as a refutation of what Hobbes had said about man in a state of nature and an affirmation of the concept of sociability. Pufendorf thought that the Treaty of Westphalia's recognition of religious diversity was a good solution to the problem of irreconcilable religious differences and was an important characteristic of that peace settlement. Pufendorf also rejected Hobbes's insistence on the need for an absolute leviathan to maintain order. The German Empire, Pufendorf believed, was not a sovereign entity, but a mixture of different forms of government that was something less than a sovereign government. ${ }^{121}$

Pufendorf also sought to reduce the occasions that led to war. In this case, he was undoubtedly thinking of the third parties that had intervened in the Thirty Years War and the numerous colonial wars of conquest. He rejected Grotius's notion that a state had a natural right to punish any other state for actions contrary to natural law, and he also insisted that punishment could not be visited on individuals who were not subjects (with certain exceptions such as pirates and bandits). What Pufendorf had in mind here was to argue that European conquerors and colonizers could not expropriate the lands of indigenous peoples in the New World simply because they engaged in barbarous and unnatural acts, such as human sacrifice and cannibalism. Pufendorf also stated that a third party could not intervene in a war that did not directly affect its own interests as a neighboring state. Otherwise, wars 
would multiply. He also condemned preemptive strikes against a possible enemy, although a state could go to the assistance of a third country to which it was bound by treaty. ${ }^{122}$

Earlier in the seventeenth century, Henry IV's minister, the Duke of Sully, had put forward his "Grand Design" for peace, which was based on accepting the religious and political status quo of the European states, except for partially dismantling the Holy Roman Empire. Territories would be taken away from the Austrian Habsburgs in order to entice the other states of Europe to join this scheme. The Habsburgs would be removed from Central Europe and confined to their Spanish dominions. These European states would then form a league to drive the Turks out of Europe. All of this, of course, necessitated making war on the Hapsburgs before taking on the Turks. If the czar of Russia, whom Sully thought of as the khan of the Scythians, did not agree to this plan, he would be confined to Asia like the Turkish sultan. Sully's "Grand Design" would have led to a European government with a composite army. Sully does not seem to have understood that his grandiose plans would have sown the seeds of revanchism among the Austrians and all the other losers, and probably would have encouraged the growth of Prussian expansion and militarism. Sully's method of bringing peace to Europe was simply another crude version of the Roman practice of first securing a total and crushing victory and then dictating a peace settlement. ${ }^{123}$

François de Callières, an envoy of Louis XIV who signed the Treaty of Ryswick in 1697, offers a complete contrast to Sully's clumsiness. Callières thought that every Christian prince had a moral obligation not to pursue war until he had made a serious attempt to settle differences with other states by peaceful means. He believed that France's lack of a system for training diplomats contrasted unfavorably with that provided for military officers. Diplomatic assignments were often given to men of little education and knowledge who had never before been out of the country. They were hardly better than the heralds of medieval times, who were sent to deliver specific messages, rather than having permanent diplomatic missions abroad, which negotiated on a continuing basis and kept their princes and governments well informed about events before they developed into crises. Callières thought that good diplomatic practice in France began only with the ministry of Cardinal Richelieu in the reign of Louis XIII. The transition from ad hoc to permanent diplomatic 
representation abroad had been necessitated by the decline of papal power and the emergence of sovereign states and shifting diplomatic alliances. The new diplomacy spread from Renaissance Italy to Northern Europe. Hugo Grotius, the most eminent jurist of the early seventeenth century, also served in a diplomatic capacity representing the Dutch Republic in England, and later, spent ten years as the Swedish ambassador to France. He looked on these roles as a painful experience, and did not believe that permanent diplomatic missions were desirable. ${ }^{124}$

William Penn, the Quaker founder of the colony of Pennsylvania, also put forward a plan for the international government of European affairs. Penn wrote his essay because he was distressed by the "bloody tragedies" of the Nine Years War (1688-97). He feared that men could not "know the comforts of peace, but by smart and penance of the vices of war." Penn proposed that the sovereign princes of Europe agree to meet every year or so in a diet or parliament to take up weighty matters and disputes that could not be resolved by embassies. These disputes would be dealt with by discussion in order to preserve peace. The states that refused to participate would be compelled to submit to arbitration by the other participating powers. Allowing a ruler to act as his own judge in a dispute was to be avoided at all costs. The weight to be assigned to the votes of large and small countries was to be determined by an estimate of the number of persons and the gross wealth of each country based on the revenue of that country. To avoid arguments about precedence in this European parliament, the chamber in which the body was to meet should be round in shape with many doors for entrance and exit. The presiding officer could be chosen "by turns." Decisions would be made only by a majority of three-quarters of the members. The language of debate should be French or Latin, the language of men of quality in the first instance, or of civil lawyers in the second. ${ }^{225}$

William Penn assumed that his proposal to establish a European parliament to preserve the peace would be met with a number of objections. One was that a prolonged peace would engender effeminacy; another was that there would "be a great want of employment for younger brothers of families; and that the poor must either turn soldiers or thieves." His reply was that, instead, society would have trade and employment for everyone. The philosophers of the eighteenth-century Enlightenment would also note the correlation among 
commerce, civil societies, and peace. Penn also argued that if the European powers adopted his proposal for universal peace, the reputation of Christianity in the sight of infidels would greatly increase. ${ }^{126}$

Another plan for universal peace and a proposal for a European union came from Charles Castel de Saint-Pierre, a French cleric. Saint-Pierre was a perpetual student, who has been called the patriarch of the philosophes and an early exponent of utilitarianism. He was secretary to Cardinal de Poligniac, one of the French emissaries who negotiated the Peace of Utrecht of 1713, which ended the War of Spanish Succession. He had lived in the Netherlands for more than a year, and his contact with Dutch intellectuals influenced his own political and economic ideas. Saint-Pierre had not heard of Emeric Crucés Nouveau Cynée, which anticipated some of his ideas until his friend Gottfried von Leibnitz made him aware of it. However, he had read the work by the Duke of Sully. ${ }^{127}$

Saint-Pierre's plan for perpetual peace proposed a republic consisting of twenty-four Christian states of Europe as defined by the Treaty of Utrecht. Each state would send the same number of delegates to a senate of peace, which would meet on a permanent basis in a neutral city such as Cologne, Geneva, or Utrecht. The presidency of that senate would rotate on a weekly basis. No state could secede from this European union. An army would be raised to protect this European union from Asiatic aggression until a similar Asian union for perpetual peace could be formed. When disagreements occurred among the European states mediation would be obligatory before a court of arbitration, which would hand down a verdict. But that verdict would go into effect only after five years. The long-term goal of Saint-Pierre's scheme for perpetual peace was disarmament, which he assumed would promote greater economic prosperity. Saint-Pierre assumed that the twenty-four states of his republic of peace would retain most of the attributes of sovereignty and continue to negotiate treaties with one another. Implicit in his plan was the assumption that the Austrian Habsburgs' pretensions to universal monarchy would be undercut. Saint-Pierre is generally regarded as a Utopian, but the ministers of the French crown of his day saw him as a "tiresome and disturbing agitator."128

After the Thirty Years War, warfare became more limited in nature. Thereafter, the thrust of philosophers such as the Swiss Emmerich de Vattel was to impose constraints on war so that as little damage was done to 
noncombatants and their property as possible. Vattel entertained no doubts about the natural right of making war. He thought only a fanatic would take seriously the pacifist message of the Gospels, and allow himself "to be massacred and plundered, rather than oppose force to violence." The right to make war belonged only to "nations" and could be employed to remedy an injustice, but only as a last resort. A just war must be publicly declared, the grievances had to be specified, and the designated enemy must be given time to reply with a proposed remedy. A defensive war, however, required no formal declaration. The only just reasons for going to war were to prevent or avenge an injury by an aggressor. Vattel did say that a preemptive strike against a neighboring state could also be justified when that state prepared for war in time of peace and refused to explain why it was doing so. ${ }^{129}$

While Vattel, like Kant, rejected the concept of an international government possessed of sovereign powers, he did believe that the states of Europe had enough in common to constitute a sort of republic. Modern Europe had a shared political system that was characterized by the exchange of resident ambassadors and a continuing process of negotiating treaties with one another for "the maintenance of order and the preservation of liberty." The states of Europe were no longer constantly at war with one another, but had achieved a degree of peace by means of what was called "the balance of power." Although the alliances in this system were constantly shifting, this did achieve a greater degree of peace than had prevailed a century earlier. ${ }^{130}$

Immanuel Kant was the first major philosopher to imagine a world free of war. From the time of the first Classical Greek philosophers, the great thinkers of the Western world had believed that war was a permanent and even dominant feature of human life. Most thinkers, although they might deplore war as evil, also viewed war as the usual path to peace. Kant was a Pietist, a Protestant sect that emphasized ethics and avoided theological dogmatism. He lived much of his life in Königsberg, East Prussia, and taught at the university there. He must have had a puckish sense of humor since he tells us that he got the idea for the title of his treatise on pacifism, Perpetual Peace (1795), from a Dutch innkeeper's sign, which depicted a graveyard. The point was that most philosophers-and rulers-assumed that war was the main theme of history because it had dominated relations between states since antiquity, and lasting peace was to be found only in the next world. ${ }^{131}$ 
Kant regarded war as a great evil and denied that it was a legitimate way to settle disputes. At the same time, he was not a pacifist, and insisted that in the long history of mankind, warfare often contributed to human progress. It had driven men to form political societies for protection, and to settle uninhabited parts of the earth. The fear of future wars had caused people to think about humanitarian values, to devise technological and scientific innovations, and generally, to pursue learning. Kant argued that war was generally "a deeply concealed, perhaps intentional attempt of the most supreme wisdom, if not to establish then at least to prepare lawfulness along with the freedom of states and thereby the unity of a morally grounded system of states." Fear of what the future might bring drives people toward progress, and hopefully, that will eventually lead to some universal scheme for preserving peace on a universal scale. All of the previous peace treaties had been mere truces. Kant looked forward to the future establishment of a kind of "representative republic," but he doubted that any of the monarchs or diplomats of his time had anything to contribute to such an idea. Kant does not precisely state what such an international organization for preserving peace would have looked like, but the model that he often employed was based on the leagues of Greek citystates, such as the Delian League. ${ }^{132}$

We hear an echo of Hobbes when Kant says that nature, by instilling in people an unsociableness that leads to wars interspersed with undeclared states of war and "unremitting military preparations," drives them by their suffering to abandon the savage state in which they exist to seek peace and security by renouncing the state of nature and uniting together to form an international federation. Human beings are violent and will fight among themselves until an "external coercive" power intervenes. A state of undeclared war was the more natural condition of mankind than peace, and it was necessary to establish a state of peace by mutual formal agreements. Otherwise, people will always regard their neighbors as enemies. In other words, they must form a civil society and agree to submit to arbitration by competent judicial authority. The establishment of a declared state of peace can occur only between two or more states that are characterized by civil societies. ${ }^{133}$

In a state of nature, sovereign states are permitted to make war on one another because there is no international legal tribunal to which they can apply for justice. In such a lawless state, sovereign entities are also free to make 
preemptive strikes on a neighbor that engages in military preparations or is pursuing territorial expansion in order to be more powerful. The existence of such an expansionist state justifies other states attempting to maintain a balance of power in order to thwart such expansion. This constitutes a condition of perpetual war, whether declared or not. Even if there are no declared hostilities, such a situation is completely devoid of justice and should be abandoned. Such states are bound to enter into a federation dedicated to mutual self-protection. In his desire to promote peace, Kant believed that the sovereign state had to be preserved; the international federation that he envisioned could not be one where sovereign rights were given up. ${ }^{134}$

Kant condemned actions that might possibly cause wars together with actions, which, undertaken during a war, might make it difficult to secure a peace settlement. He disapproved of promoting treason or rebellion within a belligerent country. He viewed assassinations and the dispatching of spies as inimical to the restoration of peace. He could not conceive of a punitive war since no international government, authority, or tribunal existed to render a judicial decision warranting punishment of a sovereign state. Although there might be occasions when one power would be justified in intervening in a civil war, such interference was best avoided until the conflict reached a critical stage. It was better to allow an independent people the opportunity to settle their own affairs. Otherwise, it "would render the autonomy of all states insecure." ${ }^{135}$

Kant believed that the "spirit of commerce" suppressed the desire to make war, and would urge nations to make peace with one another. This urge was based on self-interest and not morality. The appearance of the commercial instinct derived from the "power of money" and was an important step in the formation of a civil society. Before any system of international security among sovereign states could be established, these states must display the characteristics of a civil society. This means that each state that aspires to the status of a civil society must possess a republican constitution. This cannot be a democracy, where all citizens possess the sovereign right to make decisions, which necessarily results in a despotism, nor can it be an absolute monarchy where one person makes all the decisions. Rather, it must be a political society where all agree to abide by the rule of law and where there is a separation of the executive power from the power to legislate, and the exercise of this legislative power is based on a system of representation. ${ }^{136}$ 
Kant urged that states possessed of a "civil constitution," that is, states characterized by a civil society living under the rule of law, should form themselves into a "league of nations" with the intention of abolishing war. Such a federation could not be called a state or a union since Kant did not contemplate these states giving up their sovereignty. What he did envision them giving up was the right to make war. Having entered into such a league, they would submit their disputes to an international tribunal to be adjudicated according to the body of international law. Kant imagined this "league of nations" gradually expanding membership as more nations decided to give up war and settle their disputes by arbitration. While an international federation of states dedicated to preserving the peace was the best solution, Kant thought that the existence of many sovereign states was preferable to a "universal monarchy" because such a large and monolithic state would degenerate into a despotism. He apparently did not envision this "league of nations" extending beyond Europe. $^{137}$

Kant's Perpetual Peace, published in 1795, was one of the last works of the Enlightenment. The philosophers of the Age of Reason and the Enlightenment, by developing theories of war, helped to place constraints on how wars were fought, and thereby, helped to lay the theoretical foundation for theories on how to achieve peace. At the same time, as constraints became codified in the rules of war, they also helped prevent interstate war from degenerating into something resembling warfare between prestate tribes. ${ }^{138}$

The concept of a civil society owed but little to the world of classical antiquity, thought Adam Ferguson, a Presbyterian minister, sometime chaplain to the Black Watch Regiment, and subsequently, professor of moral philosophy at the University of Edinburgh. Modern civil societies could find nothing to admire in the methods of war practiced by ancient Greece and Rome, he insisted. The theme that Ferguson explores in his treatise The History of Progress and the Termination of the Roman Republic is that republican institutions could not work in a sprawling and expansionist state, and would result in the dominance of the of the military over civilian authorities. By contrast, the armies of the eighteenth century accepted constraints on their methods of war, and were lenient toward defeated enemies. They valued this compassion for their defeated enemies more than martial prowess. Ferguson believed that the laws of war of his time imposed constraints on how wars were conducted, and 
reflected the humane values of civil society. This was an idea that Ferguson probably got from Montesquieu. ${ }^{139}$

The concept of a civil society was thus a modern invention, although it had derived some of its elements from the ancient world. Ferguson praised the ancient Roman legacy of civil law, but he thought that the excesses of democracy in the Roman Republic had led to despotism. The decade of the 1760s were years of crisis, he said, because Britain during that period resembled the Athenian Empire and the late Roman Republic. Large-scale demobilizations during that period led to social unrest and popular tumults that could have resulted in either militarism or egalitarianism. But the government of Great Britain, he thought, had "carried the authority and government of law to the point of perfection, which they had never before attained in the history of mankind." The rights of the people were preserved in the laws, and no despotism on the part of government officials was allowed to interfere with the proceedings of the courts. In short, this was a mixed constitution where the "vigour and jealousy of a free people" guarded against the arbitrary acts of the crown and the nobility, and protected the "safety of the person and the tenure of property" far better than any other political society on the past. But the danger remained that too much democracy could destroy a political system such as that found in Great Britain. And that is why Ferguson wasted little sympathy on the American attempt to secure independence. ${ }^{140}$

Adam Smith, Ferguson's contemporary who held the chair of moral philosophy at the University of Glasgow, identified religious toleration as another important characteristic of a civil society. He believed that state churches that possessed a monopoly of religion were employed by political leaders to support their own party and often promoted violent factionalism. But if there were many religious sects-preferably two or three hundred-the clergy and adherents of those sects would learn to tolerate one another, and would be no position "to disturb the public tranquility." ${ }^{141}$

Yet, both Ferguson and Adam Smith recognized that the degree of civility that Britain had achieved by the last quarter of the eighteenth century came with risks. One of the dangers of a civil society was its reliance on standing armies consisting of professional, long-service soldiers because this inhibited the martial spirit of citizens, and made them vulnerable to a government 
backed by physical force. In Part V of his History of Civil Society, entitled "Of the Decline of Nations," Ferguson says:

The boasted refinements, then, of the polished age, are not divested of danger. They open a door, perhaps, to disaster, as wide and accessible as any they have shut. If they build walls and ramparts, they enervate the minds of those who are placed to defend them; if they form disciplined armies, they reduce the military spirit of entire nations; and by placing the sword where they have given a distaste to civil establishments, they prepare for mankind the government of force. ${ }^{142}$

Both Adam Ferguson and Adam Smith agreed that a well established commercial culture was an important characteristic of a civil society, but it also carried risks. In barbarian or prestate societies, the principal activity was making war, and this preoccupation favored the rise of successful military leaders, and usually led to monarchical government. As a political society becomes more commercialized and the subdivision of labor more specialized, citizens have less time to spare from their occupations. They become more reluctant to exercise arms in a militia, and thus, become less warlike. Commercial nations become, at the same time, more wealthy and offer the temptation to armed neighbors to invade their countries. At the point where enforcing military obligations becomes less feasible, states usually constitute standing armies in which being a soldier becomes a full-time trade requiring that they spend all their time in military training. Adam Smith was of the opinion that states that depend on militias for defense risk conquest by other powers. However, standing armies can also pose a danger unless they are well disciplined and their loyalty to the government guaranteed. ${ }^{143}$

Adam Smith thought that the martial ethos among the Athenians first began to wane when commerce with the Greek colonies and other states became important on the eve of the Peloponnesian Wars. Previously, the usual way to acquire riches had been by the spoils of war, and citizens were glad of such opportunities. Commerce gave, then, a chance to acquire wealth and luxuries and raise themselves to equality with the nobles. Smith thought that it was at the Battle of Platea in $479 \mathrm{BCE}$ that Athenian soldiers were first paid out of the public treasury; he argues that this signifies a decline of the heroic spirit and civic participation among Athenian citizens. In fact, mercenaries had been employed at least three centuries earlier in the Greek world and among its 
neighbors. But they came to be remunerated with money only in about the fifth century BCE when coinage came into general use in the Greek world. Before that, mercenaries were recompensed in other ways. ${ }^{144}$ The belief that the development of commercial society caused citizens to become more concerned with private business and less devoted to the public good was widespread in the seventeenth and eighteenth centuries. ${ }^{145}$

Commercial societies often generated a taste for luxury and consumption. This disposition was usually shared by the rulers and the aristocracy, who became disinclined to save money in peacetime. But, in time of war, governments were obliged to borrow great sums of money to expand their military and naval forces and to equip and provision the same. Merchants and manufacturers were inclined to lend money to these governments to fund the public debt in political societies where the citizens had confidence in the equitable administration of justice and the guaranty of property rights. The existence of a permanently funded public debt could, of course, make it easier for states to go to war. The availability of such large amounts of capital was thus diverted from mercantile investment, and could make wars last longer than was needful. ${ }^{146}$

Great Britain's manufactures and commerce had allowed that country to carry on wars in distant parts of the world. Britain did not depend primarily on the export of gold or the expenditure of much of the money in circulation, but derived its wealth from the export of commodities and the profits derived from the transportation of commodities-especially goods of finer quality. Thus, Britain in the eighteenth century was able to carry on wars without interruption, whereas earlier rulers often had to interrupt their wars when the money ran out. ${ }^{147}$

Immanuel Kant noticed that the existence of a permanently funded public debt allowed European countries to engage in increasingly expensive and more frequent wars. This, of course, entailed spending a larger amount of the government's revenues on standing armies. Kant believed that the very existence of standing armies was itself a provocation to neighboring states. He disapproved of the employment of mercenary soldiers, and continued to believe that a voluntary militia was all that was permissible to deter foreign aggression. Kant also believed that commercial nations, such as Great Britain, which sold government bonds to build up their financial resources to wage 
war, represented as great a threat to peace as the maintenance of standing armies. The existence of credit systems such as this represented a major obstacle to the establishment of perpetual peace, and other states were justified in forming alliances against such governments. ${ }^{148}$

Emmerich de Vattel (1714-67), however, recognized the need to maintain a standing military force if a neighboring prince also did so, but at the same time, he lamented that this was a financial burden to any state. He thought it desirable that every treaty of peace should specify "that belligerent powers should disarm on both sides" and "disband their troops." He reveals his classical republican sentiments when he notes that England, unlike most mainland European states, was not obliged to support a large standing army, which he considered to be "an instrument of despotism." And, being Swiss by birth, he was eager to proclaim the unique position of his native land, ringed as it was by natural fortifications.

Happy Switzerland! if continuing carefully to exercise her militia, she keeps herself in a condition to repel any foreign armies, without feeding a host of idle soldiers who might crush the liberties of the people, and even bid defiance to the lawful authority of the sovereign. Of this Roman legions furnish a signal instance. The happy method of a free republic-the custom of training up all her citizens to the art of war-renders the state respectable abroad, and saves it from pernicious defect at home. It would have been everywhere imitated, had the public good been everywhere the only object in view. ${ }^{149}$

Vattel anticipated the levée en masse by which the enormous armies of the wars of the French Revolution and Napoleon would be raised, but he preferred the citizens' militias to standing armies. While Vattel thought that it was preferable to call on volunteers to serve, and assumed that those "who are incapable of handling arms or supporting the fatigues of war" would be exempted, he was not prepared to say that natural law allowed an exemption to the clergy because of the strictures of canon law. He was prepared, however, to allow exemptions from military service to those clergy who performed useful religious services. But this latter category specifically excluded monks and friars. ${ }^{150}$ The growth of religious toleration was sometimes accompanied by the appearance of anticlericalism, which could work against the civilizing process. 
A number of leading French philosophes had concluded by the middle of the eighteenth century that the European monarchies of that era were obstacles to peace. Montesquieu believed that "the spirit of monarchy is war and expansion; the spirit of republics is peace and moderation." JeanJacques Rousseau thought that wars would not end until all monarchies were abolished-although he understood that this could not achieved without spilling much blood. Rousseau had a project for writing a grand treatise on political science that would replace Montesquieu's Spirit of the Laws, but it never came to fruition. He had hoped to lay out a form of government that would ensure that the law would always prevail over the mind of man. ${ }^{151}$

Rousseau was a severe, although not intellectually rigorous, critic of Hobbes. He agreed that man in a state of nature was ruled by his passions rather than reason, but he rejected the Hobbesian view that primitive man lived in a perpetual state of conflict. Only hunger could drive him to violence. Man's naturally peaceful nature was corrupted by civil society as he adopted concepts and institutions such as marriage, property, and social stratification that rested on man-made laws rather than natural law. Men became warlike only after they formed political societies, and a martial disposition was acquired only through habit and experience. In the state of nature, relations between man and man were not stable enough to constitute either a state of war or a state of peace. Quarrels among individuals came and went quickly, so personal relations did not constitute a basis for war. War became possible only when societies were formed and concepts of property were institutionalized. Man became a soldier only after he had become a citizen. War is a relationship among states, not individual persons. Thus, the age of the "noble savage" gave way to endemic warfare. ${ }^{152}$

Rousseau rejected the assertion by Hobbes that humans lived in an undeclared state of war. Rousseau believed that Hobbes confused individuals, as they supposedly lived in a state of nature (which Hobbes had never actually observed), with individuals as they actually existed in society. Rousseau believed that man was naturally inclined to peace, but the laws, as made and administered by princes to dispense justice, were merely a cover for imposing the prince's will by force. As for the so-called "rights of nations," because international law lacked sanctions, it was weaker than the law of nature. Political society represented "an artificial concord" imposed on people to make 
them fight the ruler's wars. When the first such political society was formed, others were bound to follow. The larger that political societies grew, the more likely they were to expand outward and make war. The state is an artificial creation that continues to grow, and as it feels strong or weak in comparison to other states that surround it, it tends to absorb neighboring, and especially, weaker states to strengthen its own political stability. The bigger it grows, the more dangerous its quarrels with its neighbors become. It is in the nature of well organized political societies always to be active, and the interaction among such great societies tends to produce war and mutual self-destruction. ${ }^{153}$

As for peace, Rousseau stated that it was a much broader concept than war since it encompassed meanings such as concord, unity, benevolence, and mutual affection together with a desire to preserve God's creation of humanity, but it was easily disturbed and damaged in ways that fall short of open warfare. For example, the object of a declared war might be to force the enemy to accept a peace treaty that imposed even greater harm than was done by war. ${ }^{154}$

An important milestone in the search for a science of peace was Hugo Grotius's attempt to explain the causes of war in purely secular terms. This had the effect of playing down the differences between the Catholic and Protestant camps during the age of religious wars. In his attempt to ascertain the criteria governing a just war and the methods that might or might not be employed in conducting such a war, Grotius provided a rational mode of inquiry that might be used by the non-Christian as well as the Christian world. This was to become the basis of international law. The realization of a more developed system of international law lay in the distant future; Grotius's more immediate contribution was to cite Roman historical precedents and to provide a foundation in natural and civil law for constraints on war, which pacifist idealists sometimes forget represents a praiseworthy intermediate stage in the ultimate goal of universal peace. One must first determine which actions in war are unjust before one can declare what constitutes a just war. And it is well that the international community reach agreement concerning what is lawful in war before moving on to the next step of determining how to achieve and preserve peace in future.

The message of Machiavelli, Algernon Sidney, and the English classical republicans that liberty must be contended for, suited the temper of many 
merchants and military men in the late seventeenth and eighteenth centuries, when it was combined with a disposition to expand trade and engage in empire-building. Since making war was seen to be the principal function of the state, classical republicans such as Sidney looked for competence in their military and naval commanders. However, contrary to the doctrines of the classical republicans, this goal could not be achieved through the sporadic exercises of an amateur militia, but rather required a disciplined long-service soldiery and a professional officer corps which offered careers of merit. This did not accord well with the appointment and promotion of court favorites or the martial aspirations of the aristocracy. The professionalization of the Royal Navy was achieved in the late seventeenth century in England, but the same process in the army took much longer. Although it is difficult to gauge how completely the governing classes were persuaded by the intellectual currents associated with classical republicanism, the acceptance of the idea that military preparedness, empire-building and the expansion of trade at the expense of the Dutch, the French, and the Spanish were desirable objectives helped to propel the British kingdoms and the English colonies into wars with France and its allies that lasted from 1689 to 1815, and raised Britain from the status of a third-rate power in a backwater of Europe to that of a global great power.

James Harrington was also a classical republican, but he was closer to Hobbes in his desire to maintain peace and stability. Both men had been alarmed by those passages in Thucydides' History of the Peloponnesian War, which identified democracy and demagoguery as the principal causes of internecine strife. Harrington and Hobbes attempted to avoid civil war by prescribing governments that imposed varying degrees of censorship and absolutism. Algernon Sidney was remarkably unsympathetic to this peace ethic, and insisted on the need to constantly train for war. Indeed, he welcomed the occasional war or rebellion because of fear that the nation would become effeminate and devoid of valor without the experience of armed conflict from time to time. Moreover, Sidney did not doubt that moral justification could be found for sustaining this martial ethos. The values of this bellistic culture were reiterated in a great outpouring of books on the art of war together with sermons urging a holy war against the enemies of the Protestant cause, whether Catholic or Muslim. It was this audience that John Milton had in mind when he composed his Paradise Lost. Milton understood that such an audience was 
so conditioned to the idea that war was a consequence of sin that it would do no good to offer a secular explanation for the phenomenon of war. Milton meant to condemn this disposition to war, but he had to do it in terms that were readily comprehended. Yet, his condemnation of royal tyranny and his justification of the right of a people to rebel and choose their own leaders did little to promote the cause of peace.

Thomas Hobbes's words to the effect that in a state of nature men were perpetually at war with one another, and consequently, "the life of man [was] solitary, poor, nasty, brutish and short," are frequently torn out of context and misunderstood. Hobbes insisted that the causes of this seemingly perpetual conflict rose not so much from a widespread delight in war, but rather from an ignorance of the origins of war and peace, and the failure to study those principles of moral philosophy and the laws of nature discoverable by all men which could promote peace. In other words, Hobbes insisted that the difficulty in imagining peace in this world was caused by intellectual slovenliness. This remains as true today as it was in the age of Hobbes.

In his search for a science of peace, Hobbes looked about for the causes of bellicosity and the ignorance of those principles of moral philosophy that might promote peace, and he placed the blame on several categories of people: there were the clergy of different religious persuasions who exceeded their clerical authority and promoted a diversity of religious opinion; he castigated the philosophers and authors of classical antiquity who inculcated martial values and false principles of moral philosophy together with those modern scholars and authors who continued to reiterate those values-especially those who failed to teach obedience to royal government and thought that every king was a tyrant to be overthrown; and he singled out for special disapprobation those demagogues described by Thucydides whose rhetorical excesses often helped to precipitate conflict.

Anticipating the philosophes and scholars of the Age of Reason and the Enlightenment, Hobbes wished to completely revise the curricula of schools and universities. He intended to construct a new science of humankind, and like the deists, wanted to emphasize ethics and de-emphasize theology. But, in the interests of promoting peace, he parted company with the mainstream of political philosophy in the English-speaking world by seeking to increase royal power and to reinforce the monopoly of the established religion. Although in 
his own career he deviated from many of these restraints, he could not imagine a stable political society in which there existed unrestricted intellectual inquiry, religious toleration, free speech, and popular, or even aristocratic, participation in government. Yet, we must remember that few people did more to promote rational and scientific inquiry into the topics of war and peace than Hobbes, and he certainly must be numbered among the founding fathers of political science and political psychology.

The political and moral philosophers who followed Grotius and Hobbes in the next century or so were able to envision supra-national bodies that would urge sovereign states to settle their differences by submitting them to tribunals that would render decisions based on the developing body of international law. International law was useful for imposing constraints on how wars were fought. Wars grew less frequent, but expanded in scale and length as governments increased their financial resources through improved methods of funding their public debts by issuing bonds. Consequently, wars lengthened and spread over larger geographical areas. Indeed, some of the wars of the second half of the eighteenth century were global in scale. Perhaps, only Immanuel Kant could imagine a world completely free of war, but he was unable to draw up a more specific map of how to reach that destination. It could hardly be reached without limiting the power of sovereign governments to some degree.

Probably, the best way of bringing about peace, and one over which governments had but limited control, was through the development of commerce within their societies and also with other nations. There was general agreement that the spread of commercial culture led to the decline of bellicose cultures that had been inherited from classical antiquity and the medieval world and the emergence of civil societies that were characterized by the rule of law. The more that governments were subjected to constitutional limitations and characterized by civil societies, the more they would be drawn together in peaceful commercial relations. This might be followed by international cooperation to limit wars, and possibly, abolish war altogether and settle all disputes by arbitration. Unfortunately, the growth of commerce can also lead to international and colonial competition, and does not invariably guarantee peaceful relations. Moreover, the profits of commerce, when appropriated by government in the form of taxes and investments in the public debt often continued to be spent largely on weapons and armies, which necessarily pose a risk to peace. 
